\title{
Therapeutic Targeting of the IGF Axis
}

\author{
Eliot Osher and Valentine M. Macaulay*
}

Department of Oncology, University of Oxford, Oxford, OX3 7DQ, UK

* Correspondence: valentine.macaulay@oncology.ox.ac.uk; Tel.: +44-1865617337

Received: 8 July 2019; Accepted: 9 August 2019; Published: 14 August 2019

check for updates

\begin{abstract}
The insulin like growth factor (IGF) axis plays a fundamental role in normal growth and development, and when deregulated makes an important contribution to disease. Here, we review the functions mediated by ligand-induced IGF axis activation, and discuss the evidence for the involvement of IGF signaling in the pathogenesis of cancer, endocrine disorders including acromegaly, diabetes and thyroid eye disease, skin diseases such as acne and psoriasis, and the frailty that accompanies aging. We discuss the use of IGF axis inhibitors, focusing on the different approaches that have been taken to develop effective and tolerable ways to block this important signaling pathway. We outline the advantages and disadvantages of each approach, and discuss progress in evaluating these agents, including factors that contributed to the failure of many of these novel therapeutics in early phase cancer trials. Finally, we summarize grounds for cautious optimism for ongoing and future studies of IGF blockade in cancer and non-malignant disorders including thyroid eye disease and aging.
\end{abstract}

Keywords: IGF; type 1 IGF receptor; IGF-1R; cancer; acromegaly; ophthalmopathy; IGF inhibitor

\section{Introduction}

Insulin like growth factors (IGFs) are small ( 7.5 kDa) ligands that play a critical role in many biological processes including proliferation and protection from apoptosis and normal somatic growth and development [1]. IGFs are members of a ligand family that includes insulin, a dipeptide comprised of $\mathrm{A}$ and $\mathrm{B}$ chains linked via two disulfide bonds, with a third disulfide linkage within the A chain. The two IGF ligands, IGFs-1 and 2, display $67 \%$ identity to each other and a high degree $(\sim 45-52 \%)$ of sequence homology with the $\mathrm{A}$ and $\mathrm{B}$ chains of insulin, but differ due to retention of the bridging C-domain, and a C-terminal D-domain extension [2]. Like insulin, the IGFs have three internal disulfides that maintain correct folding and permit canonical functions. The functions of IGF-1, IGF-2 and insulin are mediated through association with the cell surface receptor tyrosine kinases (RTKs) type 1 IGF receptor (IGF-1R), and insulin receptor (INSR) [3].

The high degree of homology between IGF-1R and INSR was apparent from the initial determination of the IGF-1R primary structure [4]. IGF-1R is a $\sim 440-k d a$ heterotetrameric $\alpha_{2} \beta_{2}$ receptor with $\sim 50 \%$ sequence homology to INSR, that is bound with high affinity by IGF-1 $(\sim 1-5 \mathrm{nM})$ and with significantly lower affinity ( $4-5$ fold and $>100$-fold lower, respectively) by IGF- 2 and insulin [5-7]. The two alpha subunits are extracellular and together comprise the binding site for a single molecule of ligand, whereas the two beta subunits are transmembrane structures that include the intracellular tyrosine kinase domains $[3,8]$. Ligand binding induces a conformational change that activates the $\beta$ subunit kinase domain resulting in autophosphorylation of specific tyrosine residues, which appears to be the critical step in receptor activation [9] This in turn leads to recruitment and phosphorylation of the docking proteins insulin receptor substrates (IRS-1/2) and Shc, ultimately resulting in the activation of multiple signaling pathways, of which the two most well-characterized are Phosphoinositide 3-kinase-Protein kinase B (PI3K-AKT) and RAS-Mitogen-activated protein kinase (MAPK) $[10,11]$. These pathways are also activated by other RTKs, including Epidermal growth factor 
receptor (EGFR), Fibroblast growth factor receptor (FGFR) and Hepatocyte growth factor receptor (HGFR, MET); the IGF axis is known to engage in complex cross-talk with these pathways, and also with steroid hormone nuclear receptors, cell-matrix and cell-cell adhesion signaling components [12,13].

Despite the high degree of structural homology between IGF-1R and INSR, and the fact that the receptors signal via many common mediators, the two receptor signaling axes have undergone considerable functional divergence. As will be discussed below, this close structural relationship has posed a significant problem for development of agents to block the IGF axis. The primary role of INSR is anabolic control and glucose homeostasis; the classical receptor isoform responsible for these functions is known as INSR-B [14]. INSR-B is largely expressed in adult differentiated cells, notably the key insulin target tissues liver, muscle and adipose tissue, is encoded by 22 exons (11 exons encoding the alpha subunit and 11 the beta subunit), and binds insulin with high affinity but has a very low affinity for IGFs [15]. There is also a variant isoform, INSR-A, which is encoded by 21 exons due to exon 11 skipping, resulting in the absence of a 12 amino acid sequence at the $\alpha$ subunit carboxyl terminus [16]. This isoform is expressed by fetal tissues and cancers, and is capable of being activated by insulin and IGF-2 $[17,18]$. Cells that express both IGF-1Rs and INSRs express hybrid receptors formed as heterodimers between IGF-1R and INSR-A or B, with ligand binding characteristics and functions that are not fully characterized [19]. Unlike insulin that is synthesized and stored in the $\beta$ islet cells of the pancreas and secreted in response to blood glucose, IGFs are expressed by multiple cell types and not stored prior to secretion [20]. Most circulating IGF-1/2 is secreted by the liver, IGF-1 secretion being strongly and IGF-2 weakly regulated by growth hormone (GH); indeed when first identified, IGFs were termed somatomedins, reflecting their role as GH mediators [21,22].

There are several intrinsic mechanisms in place to regulate IGF bioactivity. Firstly, the majority of circulating IGF-1/2 is present in high affinity, with a calculated dissociation constant $\left(K_{D}\right)<1 \mathrm{nM}$ in inactive complexes with IGF binding proteins (IGFBPs) [23]. IGFBPs therefore prolong the circulating half-life of IGFs, although they can undergo proteolytic cleavage to release free IGFs [24]. It is increasingly recognized that IGFBPs have more complex functions that can promote IGF bioactivity, and they also have IGF-independent functions, as reviewed by $[25,26]$. Secondly, the expression of IGF-2 is regulated by genomic imprinting, being expressed in normal tissues only from the paternal allele [27]. Thirdly, there is a type 2 IGF receptor (IGF-2R) that is structurally distinct from IGF-1R and INSR, being a monomeric transmembrane protein that acts as a scavenger for circulating IGF-2 [28].

The importance of the IGF axis in normal growth has been comprehensively studied using mouse genetics [29]. Igfr1 null mice display growth retardation, (60\% of normal birth weight,) a high rate of neonatal death due to organ hypoplasia, and persisting growth retardation ( $30 \%$ of wild-type weight) for those individuals surviving into adulthood $[29,30]$. In humans, excess GH production results in abnormally high circulating IGF-1 levels and gigantism or acromegaly, while subnormal IGF-1 levels due to GH deficiency cause dwarfism [31,32]. Laron syndrome, a rare form of dwarfism caused by GH resistance resulting from GH receptor mutation, was recognized in the late 1950s by pediatric endocrinologist Zvi Laron, and has been particularly informative for understanding the contribution of the IGF axis to cancer risk [33,34], as will be discussed below. Clinical studies have identified severe growth delay and mental retardation in individuals harboring complete or partial IGF1 or IGF1R gene deletion or point mutation, such as IGF1 V44M that results in $\sim 90$-fold reduced affinity for IGF-1R [35-37]. This review will discuss the importance of the IGF axis in human disease with an emphasis on the importance of IGF-induced IGF-1R activation, and will focus on the approaches that have been taken to inhibit this key protein-protein interaction.

\section{Disease States Characterized by IGF Axis Activation}

\subsection{Cancer}

Due to the ability of IGFs to bind potently to IGF-1R and activate pathways associated with cellular proliferation, the IGF: IGF-1R interaction has long been recognized for its contribution to 
cancer growth and propensity for metastasis [38,39]. Under normal physiological conditions IGF signaling is tightly regulated, as outlined above $[23,25,28]$. However, genetic abnormalities and/or chromosomal alterations can result in deregulated expression of IGF ligands and IGF-1R [40]. These changes can occur as primary driver events that predispose to malignancy. Examples include IGF1R gene amplification and mutation in other IGF axis genes, detected in breast cancer, gastrointestinal stromal tumor (GIST) and osteosarcoma [41-43]. Activating point mutations in IGF1R itself have not been reported, but there are reports of mutational inactivation or loss of heterozygosity of the anti-proliferative IGF2R in prostate cancer and uveal melanoma [44,45]. Loss of IGF2 imprinting has been shown to drive development of malignancy in mouse models and is associated clinically with colorectal cancer, Wilms tumor and hepatocellular carcinoma [27,46-49].

It must be acknowledged that in the majority of common solid tumors, IGF axis deregulation is not itself the driver but occurs secondary to another molecular event that influences the expression of the ligands and/or receptors. As will be seen, this lack of a driver role is an issue for clinical use of drugs that block the IGF axis, particularly when used as monotherapy. The upregulation of IGF-1R that occurs frequently in common solid tumors is often secondary to loss of the negatively regulatory influence of tumor suppressor genes including BRCA1, WT1, TP53 and vHL [50]. Even if not driver events, overexpression and/or activation of IGF axis components promotes canonical signaling via effectors including AKT and ERKs that contribute to resistance to cancer therapies including chemotherapy, radiotherapy, endocrine therapy and targeted agents [51-56]. It is increasingly recognized that tumor growth, metastasis and therapy resistance can be promoted by IGFs secreted by cellular components of the tumor stroma [57-59].

Recent studies have identified an IGF-inducible non-canonical function of IGF-1R: following internalization and clathrin-dependent endocytosis, the receptor is capable of translocating to the nucleus and acting as a transcription factor by binding to regulatory regions of DNA [60-62]. Our group has reported that nuclear IGF-1R is detectable in pre-invasive lesions and several types of invasive malignancy including prostate, renal and breast cancers, and is associated with adverse prognosis in renal cancer and advanced tumor stage in prostate cancer $[61,63]$. Furthermore, we showed that IGF-1R recruitment to the JUN and FAM21A promoters contributes to expression of these genes that mediate cell survival and motility, angiogenesis and chemo-resistance [63-65].

As well as promoting tumorigenesis and treatment resistance, IGFs contribute to the risk of developing cancer. This has been shown most clearly by the almost complete protection from cancer in patients with Laron dwarfism, who have very low levels of serum IGF-1 due to GH receptor mutation $[33,34,66]$. In addition to regulation by GH, circulating IGF-1 levels are known to be influenced by dietary factors including dairy and total protein intake [67-69]. It is now well-established that subjects in the general population who have serum IGF-1 levels at the upper end of the normal range are at increased risk of developing several types of cancer including prostate, breast and colorectal cancer [70-73].

\subsection{Endocrine Disorders}

\subsubsection{Acromegaly}

Subjects with acromegaly, which is due to excessive GH secretion, have elevated levels of serum IGF-1 and are well-recognized to be at increased risk of colorectal cancer, with possible association also with breast, thyroid and prostate cancers and a recent report of multiple additional tumors including cancers of the lung, kidney, adrenal and GIST [74,75]. There are additional health risks associated with chronic exposure to high circulating IGF-1, including increasing bone fragility. This seems paradoxical given that IGFs are required for normal bone development [76]. However, excess IGF-1 secretion has been shown to compromise bone integrity and microstructure, leading to increased risk of vertebral fracture [77]. IGFs are also important for the growth and survival of cardiomyocytes, and untreated acromegaly can cause hypertrophic cardiomyopathy leading to cardiac failure [78]. 


\subsubsection{Diabetes}

Several large longitudinal studies have investigated links between serum IGF-1 and risk of type 2 diabetes mellitus (T2DM), and have found evidence for an association between increased incidence of insulin resistance and T2DM in subjects with either low-normal or high-normal IGF-1 levels $[79,80]$. The factors contributing to this U-shaped association are incompletely understood, but may be due to the fact that IGF bioactivity is influenced not only by serum IGF-1 but also other IGF components including IGFBPs. The association with low IGF-1 is probably related to the insulin-like actions of IGF-1 that promote hypoglycemia, and the fact that IGF-1 suppresses secretion of GH, which itself causes insulin resistance [81,82]. Recombinant human IGF-1 (rhIGF-1) has been evaluated as treatment for diabetes, with evidence of improved glycemic control but significant adverse effects including worsening diabetic retinopathy $[83,84]$. Currently there are no indications for use of rhIGF-1 in diabetes treatment, but there is ongoing interest in exploiting IGF-dependent and -independent actions of IGFBPs, especially IGFBP -1 and -2 , to influence insulin sensitivity [82].

\subsubsection{Thyroid Eye Disease}

Graves' disease (GD) is an autoimmune disorder caused by pathogenic thyrotropin (thyroid stimulating hormone, TSH) receptor autoantibodies (TRAb), which have agonist TSH-like actions leading to goitre and thyrotoxicosis [85]. Between 25 and 50\% of patients with autoimmune thyroid disease develop thyroid-associated ophthalmopathy (TAO), with proptosis due to intra-orbital expansion of connective and fatty tissue [86]. Thyrotropin receptors are expressed by monocyte-derived orbital fibrocytes, which are induced by TRAbs to secrete glycosaminoglycans including hyaluronan, and pro-inflammatory cytokines including IL-16, TNF-alpha and Chemokine C-C motif ligand 5 (CCL5, RANTES) [87]. The involvement of the IGF axis in orbital tissue expansion is now well-established: IGF-1R is over-expressed by orbital fibroblasts and T and B cells of GD patients, and IGF-1 is known to synergize with thyrotropin and to regulate immune functions [88,89]. Furthermore, complexes containing thyrotropin, IGF-1R and INSR have been detected in orbital fibroblasts and thyroid epithelial cells, the IGF axis is required to maintain thyrotropin signaling, and anti-IGF-1R autoantibodies that activate IGF-1R are detectable in patients with GD [87,90,91]. Thus, although cross-talk between thyrotropin and IGF signaling has been recognized for over 30 years, it is only recently that IGF-1R activation has been implicated in driving the immunopathogenesis of GD $[87,88,92,93]$.

\subsection{Skin Diseases}

\subsubsection{Psoriasis}

IGF-1 appears to contribute to the epidermal hyperproliferation that characterises psoriasis. IGF-1Rs are upregulated in psoriatic lesions and are expressed by proliferating basal and suprabasal keratinocytes, likely accounting for the greater proliferative response to IGF-1 of keratinocytes from psoriatic skin compared with normal keratinocytes [94,95]. Reduction in IGFBP-3 expression in the epidermal rete pegs probably increases local IGF bioavailability, also contributes to increased proliferation $[96,97]$.

\subsubsection{Acne}

A link between IGF- 1 and acne is suggested by the known cross-talk between IGFs and androgens, which are implicated in acne pathogenesis [98,99], and by absence of acne in Laron dwarfs and the appearance of acne upon IGF-1 treatment [100]. In the general population, adults with acne are reported to have elevated levels of serum IGF-1, and IGF-1 levels correlate with acne severity [101,102]. The mechanism of this apparently causative association has been studied in preclinical models, where IGF-induced PI3K-AKT activation upregulates sterol-response element binding protein-1 to increase sebaceous lipogenesis, and also upregulates inflammatory cytokines $[101,103,104]$. 


\subsection{Frailty and Lifespan}

IGFs are important for maintenance of bone and muscle mass, and IGF-1 serum levels have been reported to be lower in the frail elderly compared with more robust subjects $[105,106]$. Paradoxically, the IGF axis is the target of inactivating mutations in long-lived model organisms including Caenorhabditis elegans, Drosophila melanogaster and mice $[107,108]$. Supporting the clinical relevance of these findings, IGF1R mutations in humans that attenuate IGF response have been found to be associated with longevity and a reduction in frailty [109]. Thus, there is a conflict in the literature between findings that IGFs promote muscle strength and bone density, and reports associating low IGF-1 bioactivity with reduced frailty. Potentially resolving this conflict, preclinical and population-based studies indicate that a high protein diet and high IGF-1 in middle age associate with increased cancer incidence and mortality, and promote tumour growth in mouse models, while a low protein diet and low IGF-1 are detrimental in old age [110].

\section{Therapeutic Strategies for Targeting IGF-1R in Cancer}

Given the functions of IGF-1R and the pathogenic associations of high IGF bioactivity, the IGF axis has been acknowledged as a target for therapeutic intervention. In fact, IGF-1R was the first RTK to be targeted by an inhibitory antibody in preclinical studies, when neutralizing antibody $\alpha$ IR3 was shown to inhibit growth of breast cancer cells in vitro and as xenografts in immunodeficient mice [111]. However, clinical evaluation of this approach was delayed by legitimate concerns about the potential for toxicity, due to inhibition of normal tissue IGF-1R and the co-inhibition of INSR [112,113]. From 2004-2005 onwards, a number of different strategies were developed for evaluation in the clinic. The principal strategies include molecular approaches, anti-IGF-1R antibodies, small molecule tyrosine kinase inhibitors (TKIs), IGF-1/2 neutralizing antibodies and IGF ligand TRAPs. Several reviews have addressed the important issues of clinical efficacy, the need for predictive biomarkers and selection of targets for co-inhibition e.g., [56,114-117]. We focus here on the physical properties of each class of agent and summaries their current clinical status.

\subsection{Molecular Approaches}

Prior to availability of Pharma IGF-1R inhibitory drugs, nucleic acid-based approaches were developed to target IGF-1R. The sequence specificity of these approaches generated tools that targeted IGF-1R specifically, reflecting concerns relating to INSR co-inhibition; these agents proved useful in proof of concept preclinical experiments, and some reached the clinic.

\subsubsection{Antisense Oligonucleotides}

Antisense-mediated downregulation of Igf- 1 or Igf-1r was shown to inhibit growth of murine tumors in vivo, and induce an immune response that suppressed growth of unmodified tumors in syngeneic models $[118,119]$. These data encouraged clinical testing of IGF-1R antisense oligonucleotides (ASOs) in a pilot study in patients with malignant astrocytoma. IGF-1R ASOs were transfected ex vivo into autologous tumor cells that were re-implanted into the subcutaneous tissues, with response in 8/12 patients [120]. IGF-1R ASO modified to increase stability was shown to reduce epidermal hyperproliferation in human psoriatic skin xenografts in vivo [121]. This ASO was developed as a drug, ATL1101, that was shown to inhibit growth of prostate cancer xenografts following intraperitoneal administration [122]. ATL1101 was formulated into a cream and tested in a proof of concept clinical study in patients with psoriasis, reporting evidence of clinical benefit (https://www.sec.gov/Archives/ edgar/vprr/0501/05012077.pdf), but has not apparently progressed further.

\subsection{2. siRNAs}

Soon after the fortuitous discovery of RNA interference (RNAi) in 1998, the technology was considered for therapeutic use [123]. RNAi is mediated by siRNAs, short (20-25 bp) double-stranded 
RNAs that recruit the RNA-silencing complex to silence target genes with high specificity via mRNA degradation, and can also induce epigenetic modification and transcriptional repression by interaction with the transcriptional machinery $[124,125]$. Our group reported that IGF-1R siRNA efficacy is influenced by secondary structure in Igflr mRNA, leading to design of IGF-1R siRNAs that induced profound IGF1R silencing and enhanced tumor cell radiosensitivity [126]. Subsequently, we and others showed that IGF1R gene silencing enhances sensitivity to chemotherapy, ionizing radiation and targeted agents in prostate, renal, and esophageal cancer and HCC models in vitro and in vivo [127-130]. Major issues for clinical use include siRNA delivery and stability in vivo, although stabilized siRNAs can be effective following in vivo administration [131]. Currently 62 siRNA trials are registered on https://clinicaltrials.gov, although this approach has not been pursued for IGF-1R.

\subsubsection{Dominant Negative Receptors}

Another nucleic acid-based approach to blocking IGF signaling was designed to exploit the knowledge that IGF-1R is a disulphide-bonded heterotetramer in which one molecule of ligand binds into a pocket formed of two IGF-1R alpha subunits [3,8]. Thus, the function of endogenous IGF-1R can be prevented by expression of dominant-negative receptor that complexes with a wild-type half receptor to allow ligand binding while lacking kinase activity. Dominant negative IGF-1Rs (dnIGF-1Rs) have been generated by expression of IGF-1R residues 1-486, encoding soluble receptor or IGF-1R 1-950 that is expressed at the cell surface [132-137]; these dnIGF-1Rs are capable of inducing apoptosis in vitro and inhibiting tumorigenesis and metastasis in vivo. Comparable dominant negative IGF-1R blockade has also been achieved using a mutant 'decoy' IGF-1 defective in integrin binding, which was shown to inhibit anchorage-independent growth in vitro and tumorigenesis in vivo [138]. Clinical application of the dominant negative approach is limited by technical issues related to delivery and duration of expression, and regulatory and safety considerations [139]. However, on a positive note, the preclinical efficacy of dnIGF-1Rs encouraged development of a related approach, the IGF-Trap, based on protein therapeutics (see below).

\subsection{Anti-IGF-1R Agents}

\subsubsection{IGF-1R Antibodies}

The first major Pharma agents to be tested clinically were monoclonal antibodies (mABs) that bind to the IGF-1R alpha subunit, blocking IGF binding (Figure 1). This was a logical initial approach, given concerns over the risk of side-effects due to INSR co-inhibition [112]. Indeed, these antibodies exhibit exquisite specificity for IGF-1R over INSR, as summarized in Table 1 for the eight mABs that have been evaluated in early phase trials in cancer patients. Mechanism-based studies revealed that in addition to blocking IGF ligand binding and hence IGF-induced signaling, IGF-1R antibodies induce IGF-1R internalization and degradation [140]. This property has implications for toxicity: despite negligible affinity for INSR, some mABs bind IGF1R:INSR-A/B hybrid receptors, inducing their internalization and downregulation [141,142]. This is one likely cause for dose-limiting hyperglycemia in patients treated with IGF-1R antibody; other causes include the endocrine response to IGF-1R blockade, inducing hepatic secretion of GH and IGFBPs which can impair glucose tolerance [143]. Conversely, for those antibodies that do not cause INSR co-downregulation, compensatory signaling can be generated by activation of INSR-A or -B by insulin or IGF-2 [144-149], or by crosstalk with other RTKs including EGF and MET $[150,151]$. 


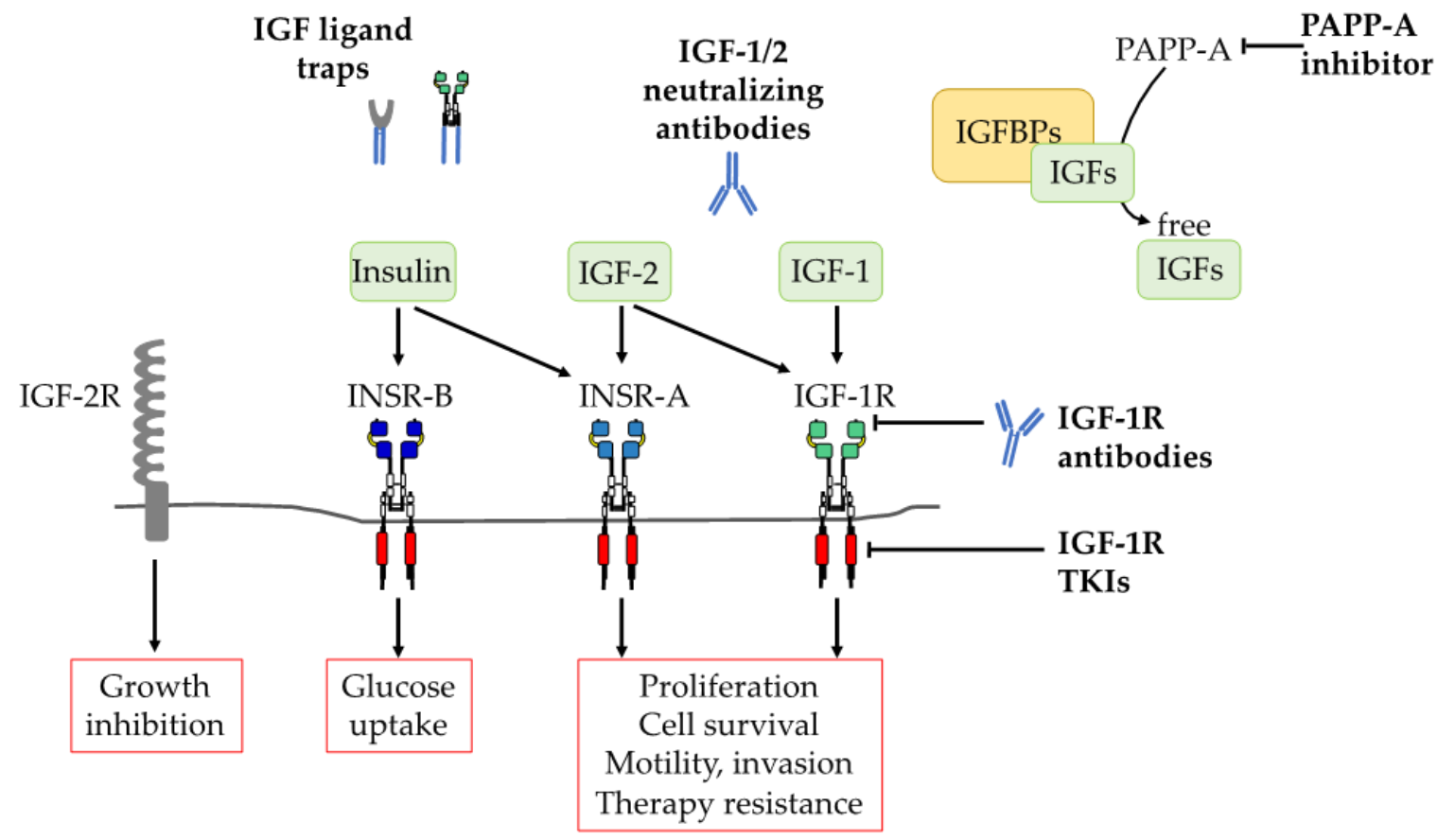

Figure 1. Overview of therapeutic strategies developed to inhibit the insulin like growth factor (IGF) axis. Figure shows the major components of the IGF axis and approaches to targeting by different classes of inhibitor. Information taken from references cited in the text.

Table 1. Anti- type 1 IGF receptor (anti-IGF-1R) antibodies evaluated in clinical trials in cancer patients.

\begin{tabular}{|c|c|c|c|c|c|c|}
\hline Antibody & Humanized & Class & $\begin{array}{l}\text { Potency }\left(\mathrm{IC}_{50}\right) \\
\text { IGF-1R }\end{array}$ & $\begin{array}{c}\text { Potency } \\
\left(\mathrm{IC}_{50}\right) \text { INSR }\end{array}$ & $\begin{array}{l}\text { Clinical } \\
\text { Trial Phase }\end{array}$ & References \\
\hline $\begin{array}{c}\text { Figitumumab } \\
(\mathrm{CP}-751,871)\end{array}$ & Fully human & IgG2a & $1.8 \mathrm{nM}$ & N/A & III & [152-156] \\
\hline $\begin{array}{l}\text { Ganitumab } \\
\text { (AMG 479) }\end{array}$ & Fully human & IgG1 & $2 \mathrm{nM}$ & $>50 \mathrm{nM}$ & III & [157-159] \\
\hline $\begin{array}{l}\text { Teprotumumab } \\
\text { (R1507) }\end{array}$ & Fully human & IgG1 & $0.5 \mathrm{nM}$ & N/A & II & [160-163] \\
\hline $\begin{array}{l}\text { Dalotuzumab } \\
\text { (MK-0646) }\end{array}$ & Humanized & IgG1 & $1 \mathrm{nM}$ & N/A & III & [164-167] \\
\hline $\begin{array}{l}\text { Cixutumumab } \\
\text { (IMC-A12) }\end{array}$ & Fully human & IgG1 & $0.6-1 \mathrm{nM}$ & N/A & II & [168-171] \\
\hline $\begin{array}{l}\text { Robatumumab } \\
\text { (SCH 717454) }\end{array}$ & Fully human & IgG1 & $2.7 \mathrm{nM}$ & N/A & II & {$[172,173]$} \\
\hline $\begin{array}{l}\text { Istiratumab } \\
\text { (MM-141) }\end{array}$ & Engineered human & $\begin{array}{l}\text { IgG1 with } \\
2 \text { scFvs }\end{array}$ & $2 \mathrm{nM}$ & $\begin{array}{c}\text { Bispecific } \\
\text { IGF-1R/ErbB3 }\end{array}$ & II & [174] \\
\hline BIIB022 & $\begin{array}{l}\text { Fully } \\
\text { human }\end{array}$ & IgG4 & $<10 \mathrm{nM}$ & N/A & I & {$[175,176]$} \\
\hline
\end{tabular}

Despite early excitement generated by the activity of IGF-1R antibodies e.g., [153,157], all the IGF-1R antibody programs have been terminated by the Pharma companies that conducted the initial development and clinical trials. Some of the trials generated evidence of activity in patient subgroups, for example in patients with high free circulating IGF-1, and those whose tumors harbored mutant KRAS [114,161,177]. However, there was little or no cross-talk between programs, so for example Dalotuzumab was tested in KRAS wild-type colorectal cancer, with no evidence of activity [167]. Patients with Ewing sarcoma have shown evidence of benefit in a number of trials [157,162,170,173]; overall, responses have been seen in $\sim 10 \%$ of Ewing patients [178]. Two drugs remain in active development. Firstly, Ganitumab was acquired from Amgen by Dr Patrick Soon-Shiong, chairman and CEO of NantCell. This antibody is currently being tested in combination with SRC inhibitor dasatinib in patients with rhabdomyosarcoma (NCT03041701), and with chemotherapy in Ewing 
sarcoma (NCT02306161), for which Ganitumab has been granted orphan drug status by the FDA. Secondly, Teprotumumab (R1507) is showing promising results in TAO, as discussed in Section 4.3.

\subsubsection{Tyrosine Kinase Inhibitors (TKIs)}

Small molecule IGF-1R TKIs were developed by Pharma to block IGF-1R kinase activity and hence suppress IGF signaling. Whilst many experimental IGF-1R TKIs have shown preclinical efficacy e.g., [179], few have undergone clinical evaluation (Table 2), and results have been disappointing. Because of high levels of sequence homology ( 85\%) between IGF-1R and INSR-A/B kinase domains, including $100 \%$ identity in the ATP-binding cleft [180], the ATP-competitive TKIs also inhibit INSR [181,182]. This can be advantageous in blocking compensatory INSR-A signaling [145] but also problematic in compromising metabolic insulin signaling via INSR-B, leading to hyperinsulinemia and dose-limiting hyperglycemia [183]. Where managed by delays and dose reductions, this and other toxicities resulted in reduced exposure to co-treatments e.g., erlotinib [184]. Furthermore, the relatively short half-life of small molecule TKIs could have resulted in only intermittent blockade of target receptors. Indeed, given understandable caution around the potential for toxicity, the linsitinib trials included formal evaluation of intermittent dosing [185-187]. It is plausible that high circulating IGF and insulin levels, induced as endocrine feedback during periods of receptor blockade, could have driven rebound tumor growth when receptors were responsive. Supporting this possibility, some patients treated with linsitinib did experience hypoglycemia $[185,186]$.

Table 2. IGF-1R Tyrosine Kinase Inhibitors (TKIs) that have undergone clinical testing.

\begin{tabular}{|c|c|c|c|c|c|c|}
\hline \multirow{2}{*}{$\begin{array}{l}\text { Drug Name } \\
\text { Linsitinib } \\
\text { (OSI-906) }\end{array}$} & \multirow{2}{*}{$\begin{array}{c}\text { Mode of Inhibition } \\
\text { ATP competitive }\end{array}$} & \multicolumn{2}{|c|}{$\begin{array}{l}\text { Potency }\left(\mathrm{IC}_{50}\right) \\
\text { IGF-1R INSR }\end{array}$} & \multirow{2}{*}{$\begin{array}{c}\begin{array}{c}\text { Additional } \\
\text { Targets }\end{array} \\
\text { N/A }\end{array}$} & \multirow{2}{*}{$\begin{array}{c}\begin{array}{c}\text { Clinical } \\
\text { Trial Phase }\end{array} \\
\text { III }\end{array}$} & \multirow{2}{*}{$\begin{array}{c}\text { References } \\
{[145,181,184-187,192,193]}\end{array}$} \\
\hline & & $35 \mathrm{nM}$ & $75 \mathrm{nM}$ & & & \\
\hline BMS-754807 & ATP competitive, & $1.8 \mathrm{nM}$ & $1.7 \mathrm{nM}$ & $\begin{array}{c}\text { MET, RON, } \\
\text { TrkA/B, AurA/B }\end{array}$ & II & {$[182,194]$} \\
\hline XL-228 & ATP competitive & $1.6 \mathrm{nM}$ & N/A & $\begin{array}{l}\text { BCR-ABL, AurA, } \\
\text { SRC, LYN }\end{array}$ & I & {$[189,195]$} \\
\hline $\begin{array}{c}\text { AXL1717 } \\
\text { (Picropodophyllin) }\end{array}$ & $\begin{array}{c}\text { Non-ATP } \\
\text { competitive }\end{array}$ & $40 \mathrm{nM}$ & N/A & Microtubules & II & {$[190,191,196,197]$} \\
\hline $\begin{array}{c}\text { Masoprocol } \\
\text { (INSM-18, } \\
\text { nordihydroguaiaretic } \\
\text { acid) }\end{array}$ & $\begin{array}{c}\text { Non-ATP } \\
\text { competitive natural } \\
\text { product of Larrea } \\
\text { divaricata }\end{array}$ & $31 \mu \mathrm{M}$ & N/A & HER2 & II & {$[188,198,199]$} \\
\hline
\end{tabular}

Non-ATP competitive IGF-1R inhibitors AXL1717 and INSM-18 inhibit IGF-1R without INSR blockade, and also inhibit additional less closely related targets [188-190]; see Table 2. The inhibition of multiple cancer targets could be advantageous, but these agents have had limited clinical success, and programs for XL-228 and INSM-18 have been discontinued. In a Phase I trial, AXL1717 induced responses in 4/9 (44\%) of patients with relapsed malignant astrocytomas [191], and has been granted orphan drug designation for this indication. Further clinical trials are planned using a new formulation (www.axelar. se/news/FDA-Grants-Orphan-Drug-Designation-for-AXL1717-for-the-Treatment-of-Glioma).

\subsection{Targeting IGF Ligands}

\subsubsection{IGF Neutralizating Antibodies}

The major issues associated with IGF-1R inhibition led to identification of an alternative therapeutic strategy that specifically targets the IGF ligands (Figure 1). Two Pharma companies generated IGF neutralizing antibodies that have entered clinical trials. Dusigitumab (MEDI-573, Medimmune) is a fully human IgG2 $\lambda$ monoclonal antibody with picomolar binding affinity for human IGF-1 and IGF-2 (KD 294 and 2 pmol/L respectively) that inhibits IGF-1 and IGF-2 -induced IGF-1R phosphorylation with $\mathrm{IC}_{50}$ concentrations of 0.97 and $0.2 \mu \mathrm{g} / \mathrm{mL}$, respectively. Thus, dusigitumab blocks IGF-induced IGF-1R and IR-A activation but has no detectable binding to insulin [200]. In a Phase I trial, dusigitumab 
was well-tolerated although without evidence of single agent activity [201]. A Phase Ib/II trial was conducted in patients with hormone receptor positive $(\mathrm{HR}+)$ metastatic breast cancer in combination with aromatase inhibitor, but there was no significant difference in progression-free survival vs. aromatase inhibitor alone (NCT01446159). Following the acquisition of Medimmune by AstraZeneca, it has been reported that the dusigitumab program is to be discontinued on the conclusion of this trial (https://labiotech.eu/medical/axed-checkpoint-inhibitor-astrazeneca/).

Boehringer Ingelheim also generated an IGF neutralizing antibody, xentuzumab (BI 836845), that blocks IGF-induced IGF-1R and INSR-A functions. This humanized IgG1 monoclonal antibody binds IGF-1 and IGF-2 with high affinity $\left(0.07\right.$ and $0.8 \mathrm{nmol} / \mathrm{L}$, respectively), with $\mathrm{IC}_{50}$ for inhibition of IGF-1R phosphorylation in response to IGF-1 of $0.6 \mathrm{nmol} / \mathrm{L}$ and IGF-2 of $7.5 \mathrm{nmol} / \mathrm{L}$ [202]. Unlike MEDI-573, xentuzumab cross-reacts with murine IGFs, allowing preclinical in vivo assessment and revealing growth inhibition in rats, and anticancer activity with rapamycin in human tumor xenografts [202,203]. Xentuzumab is being tested clinically with afatinib in EGFR-mutant lung cancer (NCT02191891), in prostate cancer with enzalutamide (NCT02204072) and in HR+ breast cancer with everolimus and exemestane (NCT02123823). In advanced prostate cancer, the addition of xentuzumab to enzalutamide did not improve outcomes overall, although there was evidence of PFS prolongation in patients with high tumor IGF1 mRNA, albeit in a small sample [204]. In breast cancer, there was evidence of activity in patients with non-visceral disease [205]. Activity in patients with predominant bone metastases may reflect preclinical evidence that tumor cells are primed to metastasize to bone by high IGF-1 secreted by stromal components of the primary tumor, suggesting that bone metastases may reflect IGF dependency [76,206]. These results have prompted a further Phase II trial of xentuzumab in breast cancer patients with non-visceral disease (NCT03659136).

\subsubsection{IGF Ligand-TRAPs}

Cell surface receptors can be targeted utilizing soluble traps that bind their ligands with high affinity, inhibiting activation of cognate receptors (Figure 1). Examples of this approach are the TNF-alpha inhibitor etanercept for treatment of rheumatoid arthritis and VEGF-TRAP aflibercept for cancer and retinal disease [207-210]. Two approaches have been taken to develop an IGF ligand trap for cancer therapy. To trap IGF-2, the ligand binding domain of IGF-2R was mutated and fused to IgG1 Fc domain to generate a homodimer capable of greatly enhanced high affinity IGF-2 binding [211,212]. Secondly, using a strategy evolved from the dnIGF-1R approach [134], an IGF-TRAP has been generated by fusing the IGF-1R extracellular domain to the $F_{c}$ region of human $\operatorname{IgG}_{1}$. This agent binds potently to both IGF ligands and much more weakly to insulin, and suppresses growth of breast cancer xenografts and colon and lung cancer liver metastases in vivo [213]. One issue for this type of Fc-fusion protein is the formation of high molecular weight complexes due to the propensity of cysteine to form disulfides between Fc fragments. To address this, the first generation IGF-TRAP has since been modified by introduction of a flexible linker and cysteine-serine substitutions in the Fc hinge region, preventing oligomer formation; this improved agent has been shown to have anti-cancer activity in an experimental colon carcinoma metastasis model [214]. There are currently no IGF-TRAPS in clinical use, but the preclinical data are promising.

\subsubsection{Recombinant IGFBPs}

Given their role as naturally occurring IGF inhibitors, IGF binding proteins have been identified as a focus for drug development. IGFBP3 is the principal circulating IGFBP, and also has IGF independent actions in the DNA damage response and EGF signaling; the latter effect is mediated by sphingosine kinase-1 (SphK1) and can be blocked by SphK1 inhibition [215,216]. Expression of recombinant human IGFBP3 (rhIGFBP3) has been explored to block IGF-dependent actions of IGFBP3, and was shown to have anticancer activity in vitro and in vivo [217]. This prompted development by Insmed of rhIGFBP3 as a protein therapeutic alongside the IGF-1R:HER2 inhibitor INSM-18, but development of both agents was subsequently discontinued. 


\subsubsection{PAPP-A Inhibition}

Pregnancy-associated plasma protein-A (PAPP-A) is a metalloprotease that enhances IGF bioactivity by proteolytic cleavage of IGFBPs, particularly IGFBP-4 [218]. Anti-PAPP-A antibody has been shown to have significant anti-cancer activity in vivo, inhibiting formation of malignant ascites in immunodeficient mice injected intraperitoneally with patient-derived ovarian cancer or ascites [219]. Reflecting the influence of IGF bioactivity on longevity, PAPP-A null mice have been found to have prolonged lifespan, significantly reduced incidence of fatal neoplasia and reduction in degenerative changes including cardiac and renal disease [220]. As a result, there is now major interest in targeting PAPP-A as an approach to block IGF bioactivity in aging research [221].

\subsection{Natural Products That Inhibit the IGF Axis}

Whilst arguably the weakest of all the therapeutic classes, natural products have been known to have medicinal benefits for centuries and are the focus of interest for early stage drug discovery [222,223]. Many naturally-occurring organic compounds have been shown to block growth factor signaling, including blockade of the IGF axis [224]. Natural products reported to inhibit IGF actions include curcumin from turmeric, genistein from soy products, and apigenin and quercetin, present in fruits, vegetables and grains [225-227]. For example, curcumin has been shown to downregulate IGF-1R and INSR in colorectal cancer cells, and to block IGF-induced activation of IGF-1R, PI3K-AKT and mTOR, suppressing carcinogen-driven skin tumorigenesis in an Igf-1 driven model $[228,229]$. This is an active area of clinical research and many trials are evaluating these agents: currently 200 for curcumin and $\sim 60$ for quercetin (https://clinicaltrials.gov).

\section{Therapeutic Use of IGF Axis Inhibitors: Current Status}

\subsection{Negative Trials of IGF-1R $m A B$ s and TKIs in Cancer Patients}

Despite encouraging results in early clinical trials, IGF-1R inhibitors have not proved to have useful single agent activity in patients with cancer, with the possible exception of Ewing sarcoma $[157,162,170,173,178]$. Factors that may contribute to lack of efficacy include compensatory signaling via INSR-A, IGF-1R:INSR hybrid receptors and other RTKs including EGFR and MET $[117,145,150,151]$. To address this issue, trials are exploring effects of multiple targeted agents in combination [230,231]. An important consideration especially for relatively short-acting IGF-1R:INSR TKIs is the potential for rebound pathway activation that may result from high IGF and insulin levels induced during periods of receptor blockade, which are then available to activate IGF-1R and INSR signaling when the receptor blockade is released $[185,186]$. This regulation of ligand levels by endocrine feedback is a factor that differentiates the IGF: insulin axis from other RTK pathways, and is clearly relevant to therapy. Another factor that could have compromised outcomes in trials of IGF-1R inhibitors with chemotherapy is the possibility that cell cycle arrest due to IGF axis inhibition may protect from phase specific cytotoxic drugs [232,233], reviewed in [56]. As a result of the negative results in Phase II and III, most of the programs have been terminated.

\subsection{Potential Grounds for Cautious Optimism}

Renato Baserga concluded his most recent review 'The decline and fall of the IGF receptor' with the words 'spes ultima dea' (hope is the last goddess) [234]. Several aspects do give grounds for cautious optimism. Firstly, single-agent activity has been observed in trials of patients with Ewing sarcoma [178], clinical evaluation of IGF-1R mAB Ganitumab is ongoing in patients with Ewing and rhabdomyosarcoma, and Ganitumab has been granted orphan drug status in Ewing sarcoma. Secondly, the development of IGF neutralizing antibodies provides a means of blocking IGF-1R and INSR-A without compromising insulin signaling via INSR-B [201,202], thereby avoiding dose-limiting hyperglycemia that contributed to adverse outcomes in IGF-1R inhibitor trials. Recent data from the Phase II trial of xentuzumab in ER+ breast cancer reported no significant hyperglycemia, and provided 
initial evidence of activity in patients with non-visceral metastases [205]. Finally, it is clear that many of the negative trials contained patients who experienced very durable, sometimes exceptional, responses, e.g., $[157,235,236]$. Much effort has gone into the search for predictive biomarkers to guide patient selection (reviewed in [56]). Although no useful biomarker has yet been identified, this information could yet be generated by preclinical research e.g., [237-239], and ongoing trials. Support for this statement comes from the preliminary evidence of benefit from xentuzumab in breast cancer patients with predominant bone metastases, and prostate cancer patients whose tumors express high IGF1 mRNA [204,205].

\subsection{Repurposing IGF Axis Inhibitors for Non-Malignant Disorders}

Considering that many anti-cancer drugs have undergone laborious and costly development and clinical testing, it is an attractive prospect to consider their re-purposing for other disorders where the IGF axis plays a fundamental role. Two disease areas in particular are the focus of active investigation, to explore the potential of IGF-1R inhibition for non-cancer indications. Firstly, as described above (Section 2.2.3.), IGF axis activation has been recognized as making a major contribution to TAO, providing the impetus for clinical trials of IGF-1R blockade. In a preclinical study, re-purposed fully human anti-IGF-1R mAB Teprotumumab (R1507, Table 1) was shown to downregulate IGF-1R and thyrotropin receptor in fibrocytes and inhibit IGF- and TSH- dependent AKT phosphorylation and TSH-mediated IL-6 and IL-8 induction [240]. In a randomized Phase II trial (NCT01868997), Teprotumumab was evaluated in patients with active, moderate-to-severe TAO, with response in 29/42 $(69 \%)$ of patients on the Teprotumumab arm compared with $9 / 45$ on placebo $(20 \%, p<0.001)$. Evidence of benefit was apparent after only 6 weeks' treatment, and Teprotumumab was well-tolerated apart from hyperglycemia in diabetic patients [241]. Outcomes of the subsequent Phase III OPTIC trial (NCT03298867) were reported in April 2019. Patients with TAO achieved significantly greater benefit from Teprotumumab compared with placebo, $82.9 \%$ vs. 9.5\% $(p<0.001)$ achieving the primary end point of $\geq 2 \mathrm{~mm}$ reduction of proptosis ( $w w w$.endocrinologyadvisor.com/home/conference-highlights/ aace-2019/teprotumumab-effectively-reduces-proptosis-in-active-thyroid-eye-disease/). These data are extremely encouraging, and support introduction of Teprotumumab as standard of care in TAO [241,242]. Secondly, given data described above (Section 2.4.) demonstrating a role for IGFs in the regulation of healthy aging [107-109], there is interest in developing approaches to block IGF signaling for this indication [243]. Support for this idea has been recently provided by a report that a murinized version of Ganitumab improved the health and lifespan of female mice when administered for 6 months from 18 months of age, the mouse equivalent of mid-50s in humans [244].

\section{Conclusions}

This review has summarized the contribution of the IGF axis to malignant and non-malignant conditions, and the main strategies that have been or are being developed to block IGF signaling. The success of Teprotumumab in TAO is encouraging, and this seems likely to be the recipient of the first license for an anti-IGF-1R agent. IGF-1R inhibitors may also continue to be a focus of interest in in aging research. While compelling preclinical data supported development of IGF-1R targeted drugs as anti-cancer treatments, there have been no unequivocally positive trials. As a result, no IGF-1R mAB or TKI is licensed for use in patients with cancer. However, reports of exceptional responders to IGF axis blockade supports the concept of IGF targeting as cancer therapy. Mature data on the efficacy of IGF neutralizing antibody xentuzumab are awaited, and there is ongoing research to identify predictive biomarkers, which are essential for effective use of any targeted therapy.

Funding: This review received no external funding.

Acknowledgments: Research in the authors' laboratory is supported by the Rosetrees Trust and John Black Foundation, Prostate Cancer Research UK and Cancer Research UK. We are grateful to Guillaume Rieunier for comments on the manuscript. 
Conflicts of Interest: Valentine M Macaulay has been a consultancy board member for Boehringer Ingelheim. Eliot Osher has no conflicts of interest to declare.

\section{References}

1. Leroith, D.; Roberts, C.T. The insulin-like growth factor system and cancer. Cancer Lett. 2003, 195, $127-137$. [CrossRef]

2. Brzozowski, A.M.; Dodson, E.J.; Dodson, G.G.; Murshudov, G.N.; Verma, C.; Turkenburg, J.P.; De Bree, F.M.; Dauter, Z. Structural Origins of the Functional Divergence of Human Insulin-Like Growth Factor-I. and Insulin. Biochemistry. 2002, 41, 9389-9397. [CrossRef]

3. De Meyts, P.; Whittaker, J. Structural biology of insulin and IGF1 receptors: Implications for drug design. Nat. Rev. Drug Discov. 2002, 1, 769-783. [CrossRef] [PubMed]

4. Ullrich, A.; Gray, A.; Tam, A.; Yang-Feng, T.; Tsubokawa, M.; Collins, C.; Henzel, W.; Le Bon, T.; Kathuria, S.; Chen, E. Insulin-like growth factor I receptor primary structure: Comparison with insulin receptor suggests structural determinants that define functional specificity. EMBO J. 1986, 5, 2503-2512. [CrossRef] [PubMed]

5. Adams, T.E.; Epa, V.C.; Garrett, T.P.J.; Ward, C.W. Structure and function of the type 1 insulin-like growth factor receptor. Cell. Mol. Life Sci. 2000, 57, 1050-1093. [CrossRef] [PubMed]

6. Forbes, B.E.; Hartfield, P.J.; McNeil, K.A.; Surinya, K.H.; Milner, S.J.; Cosgrove, L.J.; Wallace, J.C. Characteristics of binding of insulin-like growth factor (IGF)-I and IGF-II analogues to the type 1 IGF receptor determined by BIAcore analysis. Eur. J. Biochem. 2002, 269, 961-968. [CrossRef] [PubMed]

7. Denley, A.; Bonython, E.R.; Booker, G.W.; Cosgrove, L.J.; Forbes, B.; Ward, C.W.; Wallace, J.C. Structural Determinants for High-Affinity Binding of Insulin-Like Growth Factor II to Insulin Receptor (IR)-A, the Exon 11 Minus Isoform of the IR. Mol. Endocrinol. 2004, 18, 2502-2512. [CrossRef] [PubMed]

8. Xu, Y.; Kong, G.K.-W.; Menting, J.G.; Margetts, M.B.; Delaine, C.A.; Jenkin, L.M.; Kiselyov, V.V.; De Meyts, P.; Forbes, B.E.; Lawrence, M.C. How ligand binds to the type 1 insulin-like growth factor receptor. Nat. Commun. 2018, 9, 821. [CrossRef] [PubMed]

9. Kavran, J.M.; McCabe, J.M.; Byrne, P.O.; Connacher, M.K.; Wang, Z.; Ramek, A.; Sarabipour, S.; Shan, Y.; Shaw, D.E.; Hristova, K.; et al. How IGF-1 activates its receptor. eLife 2014, 3, e03772. [CrossRef] [PubMed]

10. Chitnis, M.M.; Yuen, J.S.; Protheroe, A.S.; Pollak, M.; Macaulay, V.M. The Type 1 Insulin-Like Growth Factor Receptor Pathway. Clin. Cancer Res. 2008, 14, 6364-6370. [CrossRef] [PubMed]

11. Pollak, M. The insulin and insulin-like growth factor receptor family in neoplasia: An update. Nat. Rev. Cancer 2012, 12, 159-169. [CrossRef] [PubMed]

12. Liu, C.; Zhang, Z.; Tang, H.; Jiang, Z.; You, L.; Liao, Y. Crosstalk between IGF-1R and other tumor promoting pathways. Curr. Pharm. Des. 2014, 20, 2912-2921. [CrossRef] [PubMed]

13. Cox, O.T.; O'Shea, S.; Tresse, E.; Bustamante-Garrido, M.; Kiran-Deevi, R.; O'Connor, R. IGF-1 Receptor and Adhesion Signaling: An Important Axis in Determining Cancer Cell Phenotype and Therapy Resistance. Front. Endocrinol. 2015, 6, 106. [CrossRef] [PubMed]

14. De Meyts, P. The Insulin Receptor and Its Signal Transduction Network. Available online: https://www.ncbi. nlm.nih.gov/books/NBK378978/ (accessed on 4 July 2019).

15. Sciacca, L.; Prisco, M.; Wu, A.; et al. Signaling differences from the A and B isoforms of the insulin receptor (IR) in 32D cells in the presence or absence of IR substrate-1. Endocrinology 2003, 144, 2650-2658. [CrossRef] [PubMed]

16. Moller, D.E.; Yokota, A.; Caro, J.F.; Flier, J.S. Tissue-Specific Expression of Two Alternatively Spliced Insulin Receptor mRNAs in Man. Mol. Endocrinol. 1989, 3, 1263-1269. [CrossRef]

17. Sciacca, L.; Costantino, A.; Pandini, G.; Mineo, R.; Frasca, F.; Scalia, P.; Sbraccia, P.; Goldfine, I.D.; Vigneri, R.; Belfiore, A. Insulin receptor activation by IGF-II in breast cancers: Evidence for a new autocrine/paracrine mechanism. Oncogene 1999, 18, 2471-2479. [CrossRef] [PubMed]

18. Vella, V.; Pandini, G.; Sciacca, L.; Mineo, R.; Vigneri, R.; Pezzino, V.; Belfiore, A. A Novel Autocrine Loop Involving IGF-II and the Insulin Receptor Isoform-A Stimulates Growth of Thyroid Cancer. J. Clin. Endocrinol. Metab. 2002, 87, 245-254. [CrossRef]

19. Belfiore, A.; Frasca, F.; Pandini, G.; Sciacca, L.; Vigneri, R. Insulin Receptor Isoforms and Insulin Receptor/Insulin-Like Growth Factor Receptor Hybrids in Physiology and Disease. Endocr. Rev. 2009, 30, 586-623. [CrossRef] 
20. Zapf, J.; Froesch, E. Insulin-Like Growth Factors/Somatomedins: Structure, Secretion, Biological Actions and Physiological Role. Horm. Res. 1986, 24, 121-130. [CrossRef]

21. Salmon, W.D.; Daughaday, W.H. A hormonally controlled serum factor which stimulates sulfate incorporation by cartilage in vitro. J. Lab. Clin. Med. 1957, 49, 825-836.

22. Yakar, S.; Pennisi, P.; Kim, C.H.; Zhao, H.; Toyoshima, Y.; Gavrilova, O.; Leroith, D. Studies involving the GH-IGF axis: Lessons from IGF-I and IGF-I receptor gene targeting mouse models. J. Endocrinol. Investig. 2005, 28, 19-22.

23. Bach, L.A. IGF-binding proteins. J Mol Endocrinol. 2018, 61, T11-T28. [CrossRef]

24. Collett-Solberg, P.F.; Cohen, P. The role of the insulin-like growth factor binding proteins and the IGFBP proteases in modulating IGF action. Endocrinol. Metab. Clin. North Am. 1996, 25, 591-614. [CrossRef]

25. Forbes, B.E.; McCarthy, P.; Norton, R.S. Insulin-Like Growth Factor Binding Proteins: A Structural Perspective. Front. Endocrinol. 2012, 3, 38. [CrossRef]

26. Baxter, R.C. IGF binding proteins in cancer: Mechanistic and clinical insights. Nat. Rev. Cancer 2014, 14, 329-341. [CrossRef]

27. Bergman, D.; Halje, M.; Nordin, M.; Engström, W. Insulin-Like Growth Factor 2 in Development and Disease: A Mini-Review. Gerontology 2013, 59, 240-249. [CrossRef]

28. Williams, C.; Rezgui, D.; Prince, S.N.; Zaccheo, O.J.; Foulstone, E.J.; Forbes, B.E.; Norton, R.S.; Crosby, J.; Hassan, A.B.; Crump, M.P. Structural Insights into the Interaction of Insulin-like Growth Factor 2 with IGF2R Domain 11. Structure 2007, 15, 1065-1078. [CrossRef]

29. Liu, J.-P.; Baker, J.; Perkins, A.S.; Robertson, E.J.; Efstratiadis, A. Mice carrying null mutations of the genes encoding insulin-like growth factor I (Igf-1) and type 1 IGF receptor (Igf1r). Cell 1993, 75, 59-72. [CrossRef]

30. Baker, J.; Liu, J.-P.; Robertson, E.J.; Efstratiadis, A. Role of insulin-like growth factors in embryonic and postnatal growth. Cell 1993, 75, 73-82. [CrossRef]

31. Baumann, G. Genetic characterization of growth hormone deficiency and resistance: Implications for treatment with recombinant growth hormone. Am. J. PharmacoGenomics 2002, 2, 93-111. [CrossRef]

32. Colao, A.; Grasso, L.F.S.; Giustina, A.; Melmed, S.; Chanson, P.; Pereira, A.M.; Pivonello, R. Acromegaly. Nat. Rev. Dis. Prim. 2019, 5, 20. [CrossRef]

33. Guevara-Aguirre, J.; Balasubramanian, P.; Guevara-Aguirre, M.; Wei, M.; Madia, F.; Cheng, C.-W.; Hwang, D.; Martin-Montalvo, A.; Saavedra, J.; et al. Growth Hormone Receptor Deficiency is Associated With a Major Reduction in Pro-aging Signaling, Cancer and Diabetes in Humans. Sci. Transl. Med. 2011, 3, 70ra13. [CrossRef]

34. Laron, Z. Lessons from 50 years of study of Laron syndrome. Endocr. Pract. 2015, 21, 1395-1402. [CrossRef]

35. Woods, K.A.; Savage, M.O.; Clark, A.J.; Camacho-Hubner, C. Intrauterine Growth Retardation and Postnatal Growth Failure Associated with Deletion of the Insulin-Like Growth Factor I Gene. New Engl. J. Med. 1996, 335, 1363-1367. [CrossRef]

36. Carvalho, J.A.R.; Stannard, B.; Boguszewski, M.C.S.; Sandrini, R.; Malozowski, S.N.; De Lacerda, L.; Werner, H.; Leroith, D.; Underwood, L.E. In vitro and in vivo responses to short-term recombinant human insulin-like growth factor-1 (IGF-I) in a severely growth-retarded girl with ring chromosome 15 and deletion of a single allele for the type 1 IGF receptor gene. Clin. Endocrinol. 1999, 51, 541-550.

37. Denley, A.; Wang, C.C.; McNeil, K.A.; Walenkamp, M.J.E.; Van Duyvenvoorde, H.; Wit, J.M.; Wallace, J.C.; Norton, R.S.; Karperien, M.; Forbes, B.E. Structural and Functional Characteristics of the Val44Met Insulin-Like Growth Factor I Missense Mutation: Correlation with Effects on Growth and Development. Mol. Endocrinol. 2005, 19, 711-721. [CrossRef]

38. Samani, A.A.; Zhang, D.; Brodt, P. The Role of the IGF-I Receptor in the Regulation of Matrix Metalloproteinases, Tumor Invasion and Metastasis. Horm. Metab. Res. 2003, 35, 802-808.

39. Brodt, P.; Fallavollita, L.; Samani, A.A.; Zhang, D.; Khatib, A.-M. Cooperative Regulation of the Invasive and Metastatic Phenotypes by Different Domains of the Type I Insulin-like Growth Factor Receptor $\beta$ Subunit. J. Boil. Chem. 2001, 276, 33608-33615. [CrossRef]

40. Takeuchi, K.; Ito, F. Receptor tyrosine kinases and targeted cancer therapeutics. Boil. Pharm. Bull. 2011, 34, 1774-1780. [CrossRef]

41. Nik-Zainal, S.; Davies, H.; Staaf, J.; Ramakrishna, M.; Glodzik, D.; Zou, X.; Martincorena, I.; Alexandrov, L.B.; Martin, S.; Wedge, D.C.; et al. Landscape of somatic mutations in 560 breast cancer whole genome sequences. Nature 2016, 534, 47-54. [CrossRef] 
42. Tarn, C.; Rink, L.; Merkel, E.; Flieder, D.; Pathak, H.; Koumbi, D.; Testa, J.R.; Eisenberg, B.; Von Mehren, M.; Godwin, A.K. Insulin-like growth factor 1 receptor is a potential therapeutic target for gastrointestinal stromal tumors. Proc. Natl. Acad. Sci. USA 2008, 105, 8387-8392. [CrossRef]

43. Behjati, S.; Tarpey, P.S.; Haase, K.; Ye, H.; Young, M.D.; Alexandrov, L.B.; Farndon, S.J.; Collord, G.; Wedge, D.C.; Martincorena, I.; et al. Recurrent mutation of IGF signalling genes and distinct patterns of genomic rearrangement in osteosarcoma. Nat. Commun. 2017, 8, 15936. [CrossRef]

44. Hu, C.K.; McCall, S.; Madden, J.; Huang, H.; Clough, R.; Jirtle, R.L.; Anscher, M.S. Loss of heterozygosity of M6P/IGF2R gene is an early event in the development of prostate cancer. Prostate Cancer Prostatic Dis. 2006, 9, 62-67. [CrossRef]

45. Iida, Y.; Salomon, M.P.; Hata, K.; Tran, K.; Ohe, S.; Griffiths, C.F.; Hsu, S.C.; Nelson, N.; Hoon, D.S.B. Predominance of triple wild-type and IGF2R mutations in mucosal melanomas. BMC Cancer 2018, 18, 1054. [CrossRef]

46. Cui, H.; Cruz-Correa, M.; Giardiello, F.M.; Hutcheon, D.F.; Kafonek, D.R.; Brandenburg, S.; Wu, Y.; He, X.; Powe, N.R.; Feinberg, A.P. Loss of IGF2 Imprinting: A Potential Marker of Colorectal Cancer Risk. Science 2003, 299, 1753-1755. [CrossRef]

47. Riccio, A.; Sparago, A.; Verde, G.; De Crescenzo, A.; Citro, V.; Cubellis, M.V.; Ferrero, G.B.; Silengo, M.C.; Russo, S.; Larizza, L.; et al. Inherited and Sporadic Epimutations at the IGF2-H19 Locus in Beckwith-Wiedemann Syndrome and Wilms' Tumor. Dev.Pancreas and Neonatal Diabetes 2009, 14, 1-9.

48. Breuhahn, K.; Schirmacher, P. Reactivation of the insulin-like growth factor-II signaling pathway in human hepatocellular carcinoma. World J. Gastroenterol. 2008, 14, 1690-1698. [CrossRef]

49. Damaschke, N.A.; Yang, B.; Bhusari, S.; Avilla, M.; Zhong, W.; Blute, M.L.; Huang, W.; Jarrard, D.F. Loss of IGF2 gene Imprinting in Murine Prostate Promotes Widespread Neoplastic Growth. Cancer Res. 2017, 77, 5236-5247. [CrossRef]

50. Werner, H. Tumor suppressors govern insulin-like growth factor signaling pathways: Implications in metabolism and cancer. Oncogene 2012, 31, 2703-2714. [CrossRef]

51. Vidal, S.J.; Rodriguez-Bravo, V.; Quinn, S.A.; Rodriguez-Barrueco, R.; Lujambio, A.; Williams, E.; Sun, X.; De La Iglesia-Vicente, J.; Lee, A.; Readhead, B.; et al. A Targetable GATA2-IGF2 Axis Confers Aggressiveness in Lethal Prostate Cancer. Cancer Cell 2015, 27, 223-239. [CrossRef]

52. Chitnis, M.M.; Lodhia, K.A.; Aleksic, T.; Gao, S.; Protheroe, AS.; Macaulay, VM. IGF-1R inhibition enhances radiosensitivity and delays double-strand break repair by both non-homologous end-joining and homologous recombination. Oncogene 2014, 33, 5262-5273. [CrossRef]

53. Aleksic, T.; Verrill, C.; Bryant, R.J.; Han, C.; Worrall, A.R.; Brureau, L.; Larré, S.; Higgins, G.S.; Fazal, F.; Sabbagh, A.; et al. IGF-1R associates with adverse outcomes after radical radiotherapy for prostate cancer. Br. J. Cancer 2017, 117, 1600-1606. [CrossRef]

54. Wu, J.D.; Odman, A.; Higgins, L.M.; Haugk, K.; Ludwig, D.L.; Vessella, R.; Plymate, S.R. In vivo Effects of the Human Type I Insulin-Like Growth Factor Receptor Antibody A12 on Androgen-Dependent and Androgen-Independent Xenograft Human Prostate Tumors. Clin. Cancer Res. 2005, 11, 3065-3074. [CrossRef]

55. Quail, D.F.; Bowman, R.L.; Akkari, L.; Quick, M.L.; Schuhmacher, A.J.; Huse, J.T.; Holland, E.C.; Sutton, J.C.; Joyce, J.A. The tumor microenvironment underlies acquired resistance to CSF1R inhibition in gliomas. Science 2016, 352, aad3018. [CrossRef]

56. Simpson, A.; Petnga, W.; Macaulay, V.M.; Weyer-Czernilofsky, U.; Bogenrieder, T. Insulin-Like Growth Factor (IGF) Pathway Targeting in Cancer: Role of the IGF Axis and Opportunities for Future Combination Studies. Target. Oncol. 2017, 12, 571-597. [CrossRef]

57. Lee, J.S.; Kang, J.H.; Boo, H.J.; Hwang, SJ.; Hong, S.; Lee, SC.; Park, YJ.; Chung, TM.; Youn, H.; Mi Lee, S.; et al. STAT3-mediated IGF-2 secretion in the tumor microenvironment elicits innate resistance to anti-IGF-1R antibody. Nat. Commun. 2015, 6, 8499. [CrossRef]

58. Unger, C.; Kramer, N.; Unterleuthner, D.; Scherzer, M.; Burian, A.; Rudisch, A.; Stadler, M.; Schlederer, M.; Lenhardt, D.; Riedl, A.; et al. Stromal-derived IGF2 promotes colon cancer progression via paracrine and autocrine mechanisms. Oncogene 2017, 36, 5341-5355. [CrossRef]

59. Mutgan, A.C.; Besikcioglu, H.E.; Wang, S.; Friess, H.; Ceyhan, G.O.; Demir, I.E. Insulin/IGF-driven cancer cell-stroma crosstalk as a novel therapeutic target in pancreatic cancer. Mol. Cancer 2018, 17, 66. [CrossRef]

60. Sehat, B.; Tofigh, A.; Lin, Y.; Trocmé, E.; Liljedahl, U.; Lagergren, J.; Larsson, O. SUMOylation Mediates the Nuclear Translocation and Signaling of the IGF-1 Receptor. Sci. Signal. 2010, 3, ra10. [CrossRef] 
61. Aleksic, T.; Chitnis, M.M.; Perestenko, O.V.; Gao, S.; Thomas, P.H.; Turner, G.D.; Protheroe, A.S.; Howarth, M.; Macaulay, V.M. Type 1 insulin-like growth factor receptor translocates to the nucleus of human tumor cells. Cancer Res. 2010, 70, 6412-6419. [CrossRef]

62. Sarfstein, R.; Pasmanik-Chor, M.; Yeheskel, A.; Edry, L.; Shomron, N.; Warman, N.; Wertheimer, E.; Maor, S.; Shochat, L.; Werner, H. Insulin-like growth factor-I receptor (IGF-IR) translocates to nucleus and autoregulates IGF-IR gene expression in breast cancer cells. J. Biol. Chem. 2012, 287, 2766-2776. [CrossRef]

63. Aleksic, T.; Gray, N.; Wu, X.; Rieunier, G.; Osher, E.; Mills, J.; Verrill, C.; Bryant, R.J.; Han, C.; Hutchinson, K.; et al. Nuclear IGF-1R interacts with regulatory regions of chromatin to promote RNA polymerase II recruitment and gene expression associated with advanced tumor stage. Cancer Res. 2018, 78, 3497-3509. [CrossRef]

64. Vleugel, M.M.; Greijer, A.E.; Bos, R.; Van Der Wall, E.; Van Diest, P.J. c-Jun activation is associated with proliferation and angiogenesis in invasive breast cancer. Hum. Pathol. 2006, 37, 668-674. [CrossRef]

65. Deng, Z.H.; Gomez, T.S.; Osborne, D.G.; Phillips-Krawczak, C.A.; Zhang, J.S.; Billadeau, D.D. Nuclear FAM21 participates in NF-kappaB-dependent gene regulation in pancreatic cancer cells. J. Cell Sci. 2015, 128, 373-384. [CrossRef]

66. Steuerman, R.; Shevah, O.; Laron, Z. Congenital IGF1 deficiency tends to confer protection against post-natal development of malignancies. Eur. J. Endocrinol. 2011, 164, 485-489. [CrossRef]

67. Allen, N.E.; Appleby, P.N.; Davey, G.K.; Key, T.J. Hormones and diet: Low insulin-like growth factor-I but normal bioavailable androgens in vegan men. Br. J. Cancer 2000, 83, 95-97. [CrossRef]

68. Allen, N.E.; Appleby, P.N.; Davey, G.K.; Kaaks, R.; Rinaldi, S.; Key, T.J. The associations of diet with serum insulin-like growth factor I and its main binding proteins in 292 women meat-eaters, vegetarians, and vegans. Cancer Epidemiol. Biomark. Prev. 2002, 11, 1441-1448.

69. Smith, W.J.; Underwood, L.E.; Clemmons, D.R. Effects of caloric or protein restriction on insulin-like growth factor-I (IGF-I) and IGF-binding proteins in children and adults. J. Clin. Endocrinol. Metab. 1995, 80, 443-449.

70. Renehan, A.G.; Zwahlen, M.; Minder, C.; O’Dwyer, S.T.; Shalet, S.M.; Egger, M. Insulin-like growth factor (IGF)-I, IGF binding protein-3, and cancer risk: Systematic review and meta-regression analysis. Lancet 2004, 363, 1346-1353. [CrossRef]

71. Travis, R.C.; Appleby, P.N.; Martin, R.M.; Holly, J.M.; Albanes, D.; Black, A.; Bueno-De-Mesquita, H.; Chan, J.M.; Chen, C.; Chirlaque, M.-D.; et al. A meta-analysis of individual participant data reveals an association between circulating levels of IGF-I and prostate cancer risk. Cancer Res. 2016, 76, 2288-2300. [CrossRef]

72. Ma, J.; Giovannucci, E.; Pollak, M.; Stampfer, M. RESPONSE: Re: Prospective Study of Colorectal Cancer Risk in Men and Plasma Levels of Insulin-Like Growth Factor (IGF)-I and IGF-Binding Protein-3. J. Natl. Cancer Inst. 1999, 91, 2052. [CrossRef]

73. Key, T.J.; Appleby, P.N.; Reeves, G.K.; Roddam, A.W. Insulin-like growth factor 1 (IGF1), IGF binding protein 3 (IGFBP3), and breast cancer risk: Pooled individual data analysis of 17 prospective studies. Lancet Oncol. 2010, 11, 530-542.

74. Boguszewski, C.L.; Ayuk, J. MANAGEMENT OF ENDOCRINE DISEASE: Acromegaly and cancer: An old debate revisited. Eur. J. Endocrinol. 2016, 175, R147-R156. [CrossRef]

75. Jawiarczyk-Przybyłowska, A.; Wojtczak, B.; Whitworth, J.; Sutkowski, K.; Bidlingmaier, M.; Korbonits, M.; Bolanowski, M. Acromegaly associated with GIST, non-small cell lung carcinoma, clear cell renal carcinoma, multiple myeloma, medulla oblongata tumour, adrenal adenoma, and follicular thyroid nodules. Endokrynol. Pol. 2019, 70, 213-217. [CrossRef]

76. Rieunier, G.; Wu, X.; Macaulay, V.M.; Lee, A.V.; Weyer-Czernilofsky, U.; Bogenrieder, T. Bad to the Bone: The Role of the Insulin-Like Growth Factor Axis in Osseous Metastasis. Clin. Cancer Res. 2019, 25, 3479-3485. [CrossRef]

77. Mazziotti, G.A.; Lania, A.G.; Canalis, E.; Lania, A. Management of endocrine disease: Bone disorders associated with acromegaly: Mechanisms and treatment. Eur. J. Endocrinol. 2019, 181, R45-R56. [CrossRef]

78. Colao, A.; Grasso, L.F.; Di Somma, C.; Pivonello, R. Acromegaly and Heart Failure. Hear Fail. Clin. 2019, 15, 399-408. [CrossRef]

79. Schneider, H.J.; Friedrich, N.; Klotsche, J.; Schipf, S.; Nauck, M.; Völzke, H.; Sievers, C.; Pieper, L.; März, W.; Wittchen, H.-U.; et al. Prediction of incident diabetes mellitus by baseline IGF1 levels. Eur. J. Endocrinol. 2011, 164, 223-229. [CrossRef] 
80. Friedrich, N.; Thuesen, B.; Jorgensen, T.; Juul, A.; Spielhagen, C.; Wallaschofksi, H.; Linneberg, A. The association between IGF-I and insulin resistance: A general population study in Danish adults. Diabetes Care 2012, 35, 768-773. [CrossRef]

81. Smith, T.R.; Elmendorf, J.S.; David, T.S.; Turinsky, J. Growth hormone-induced insulin resistance: Role of the insulin receptor, IRS-1, GLUT-1, and GLUT-4. Am. J. Physiol. Metab. 1997, 272, 1071-1079. [CrossRef]

82. Haywood, N.J.; Slater, T.A.; Matthews, C.J.; Wheatcroft, S.B. The insulin like growth factor and binding protein family: Novel therapeutic targets in obesity \& diabetes. Mol. Metab. 2019, 19, 86-96. [CrossRef]

83. Moses, A.C.; Young, S.C.; Morrow, L.A.; O’Brien, M.; Clemmons, D.R. Recombinant Human Insulin-Like Growth Factor I Increases Insulin Sensitivity and Improves Glycemic Control in Type II Diabetes. Diabetes 1996, 45, 91-100. [CrossRef]

84. Kim, R.J.; Grimberg, A. POTENTIAL NON-GROWTH USES OF rhIGF-I. Growth, Genet. Horm. 2007, $23,1-7$.

85. Morshed, S.A.; Davies, T.F. Graves' Disease Mechanisms: The Role of Stimulating, Blocking, and Cleavage Region TSH Receptor Antibodies. Horm. Metab. Res. 2015, 47, 727-734. [CrossRef]

86. Dolman, P.J. Evaluating Graves' orbitopathy. Best Pract. Res. Clin. Endocrinol. Metab. 2012, 26, $229-248$. [CrossRef]

87. Smith, T.J.; Janssen, J. Insulin-like Growth Factor-I Receptor and Thyroid-Associated Ophthalmopathy. Endocr. Rev. 2019, 40, 236-267. [CrossRef]

88. Tramontano, D.; Cushing, G.W.; Moses, A.C.; Ingbar, S.H. Insulin-like growth factor-i stimulates the growth of rat thyroid cells in culture and synergizes the stimulation of dna synthesis induced by tsh and graves'-igg. Endocrinol 1986, 119, 940-942. [CrossRef]

89. Smith, T.J. Insulin-Like Growth Factor-I Regulation of Immune Function: A Potential Therapeutic Target in Autoimmune Diseases? Pharmacol. Rev. 2010, 62, 199-236. [CrossRef]

90. Weightman, D.R.; Perros, P.; Sherif, I.H.; Kendall-Taylor, P. Autoantibodies to Igf-1 Binding Sites in Thyroid Associated Ophthalmopathy. Autoimmun 1993, 16, 251-257. [CrossRef]

91. Pritchard, J.; Han, R.; Horst, N.; Cruikshank, W.W.; Smith, T.J. Immunoglobulin Activation of T Cell Chemoattractant Expression in Fibroblasts from Patients with Graves' Disease Is Mediated Through the Insulin-Like Growth Factor I Receptor Pathway. J. Immunol. 2003, 170, 6348-6354. [CrossRef]

92. Loos, U.; Minich, W.B. Detection of functionally different types of pathological autoantibodies against thyrotropin receptor in Graves' patients sera by luminescent immunoprecipitation analysis. Exp. Clin. Endocrinol. Diabetes 2000, 108, 110-119.

93. Martin, S.; Sirbu, A.; Betivoiu, M.; Florea, S.; Barbu, C.; Fica, S. IGF1 deficiency in newly diagnosed Graves' disease patients. Hormes 2015, 14, 651-659.

94. Ristow, H.J. Effect of insulin-like growth factor-I/somatomedin C on thymidine incorporation in cultured psoriatic keratinocytes after growth arrest in growth factor-free medium. Growth Regul. 1993, 3, 129-137.

95. Hodak, E.; Gottlieb, A.B.; Anzilotti, M.; Krueger, J.G. The Insulin-like Growth Factor 1 Receptor Is Expressed by Epithelial Cells with Proliferative Potential in Human Epidermis and Skin Appendages: Correlation of Increased Expression with Epidermal Hyperplasia. J. Investig. Dermatol. 1996, 106, 564-570. [CrossRef]

96. Xu, S.; Cwyfan-Hughes, S.C.; Van Der Stappen, J.W.; Sansom, J.; Burton, J.L.; Donnelly, M.; Holly, J.M.P. Altered Insulin-like Growth Factor-II (IGF-II) Level and IGF-Binding Protein-3 (IGFBP-3) Protease Activity in Interstitial Fluid Taken from the Skin Lesion of Psoriasis. J. Investig. Dermatol. 1996, 106, 109-112. [CrossRef]

97. Wraight, C.J.; Edmondson, S.R.; Fortune, D.W.; Varigos, G.; Werther, G.A. Expression of Insulin-Like Growth Factor Binding Protein-3 (IGFBP-3) in the Psoriatic Lesion. J. Investig. Dermatol. 1997, 108, 452-456. [CrossRef]

98. Culig, Z. Androgen receptor cross-talk with cell signalling pathways. Growth Factors 2004, 22, $179-184$. [CrossRef]

99. Melnik, B.C.; John, S.M.; Schmitz, G. Over-stimulation of insulin/IGF-1 signaling by western diet may promote diseases of civilization: Lessons learnt from laron syndrome. Nutr. Metab. 2011, 8, 41. [CrossRef]

100. Ben-Amitai, D.; Laron, Z. Effect of insulin-like growth factor-1 deficiency or administration on the occurrence of acne. J. Eur. Acad. Dermatol. Venereol 2011, 25, 950-954. [CrossRef]

101. Danby, F.W. Nutrition and acne. Clin. Dermatol. 2010, 28, 598-604. [CrossRef]

102. Rahaman, S.M.A.; De, D.; Handa, S.; Pal, A.; Sachdeva, N.; Ghosh, T.; Kamboj, P. Association of insulin-like growth factor (IGF)-1 gene polymorphisms with plasma levels of IGF-1 and acne severity. J. Am. Acad. Dermatol. 2016, 75, 768-773. [CrossRef] 
103. Smith, T.M.; Gilliland, K.; Clawson, G.A.; Thiboutot, D. IGF-1 induces SREBP-1 expression and lipogenesis in SEB-1 sebocytes via activation of the phosphoinositide 3-kinase/Akt pathway. J. Invest. Dermatol. 2008, 128, 1286-1293. [CrossRef]

104. Kim, H.; Moon, S.Y.; Sohn, M.Y.; Lee, W.J. Insulin-Like Growth Factor-1 Increases the Expression of Inflammatory Biomarkers and Sebum Production in Cultured Sebocytes. Ann. Dermatol. 2017, 29, $20-25$. [CrossRef]

105. Mohamad, M.I.; Khater, M.S. Evaluation of insulin like growth factor-1 (IGF-1) level and its impact on muscle and bone mineral density in frail elderly male. Arch. Gerontol. Geriatr. 2015, 60, 124-127. [CrossRef]

106. Doi, T.; Shimada, H.; Makizako, H.; Tsutsumimoto, K.; Hotta, R.; Nakakubo, S.; Suzuki, T. Insulin-like growth factor-1 related to disability among older adults. J. Gerontol. A. 2015, 71, 797-802. [CrossRef]

107. Altintas, O.; Park, S.; Lee, S.J. The role of insulin/IGF-1 signaling in the longevity of model invertebrates, C. elegans and D. melanogaster. BMB Rep. 2016, 49, 81-92. [CrossRef]

108. Holzenberger, M.; Dupont, J.; Ducos, B.; Leneuve, P.; Géloën, A.; Even, P.C.; Cervera, P.; Le Bouc, Y. IGF-1 receptor regulates lifespan and resistance to oxidative stress in mice. Nature 2003, 421, 182-187. [CrossRef]

109. Milman, S.; Atzmon, G.; Huffman, D.M.; Wan, J.; Crandall, J.P.; Cohen, P.; Barzilai, N. Low insulin-like growth factor-1 level predicts survival in humans with exceptional longevity. Aging Cell 2014, 13, 769-771. [CrossRef]

110. Levine, M.E.; Suarez, J.A.; Brandhorst, S.; Balasubramanian, P.; Cheng, C.-W.; Madia, F.; Fontana, L.; Mirisola, M.G.; Guevara-Aguirre, J.; Wan, J.; et al. Low Protein Intake is Associated with a Major Reduction in IGF-1, Cancer, and Overall Mortality in the 65 and Younger but Not Older Population. Cell Metab. 2014, 19, 407-417. [CrossRef]

111. Arteaga, C.L.; Kitten, L.J.; Coronado, E.B.; Jacobs, S.; Kull, F.C.; Allred, D.C.; Osborne, C.K. Blockade of the type I somatomedin receptor inhibits growth of human breast cancer cells in athymic mice. J. Clin. Investig. 1989, 84, 1418-1423. [CrossRef]

112. Macaulay, V. Insulin-like growth factors and cancer. Br. J. Cancer 1992, 65, 311-320. [CrossRef]

113. Li, R.; Pourpak, A.; Morris, S.W. Inhibition of the Insulin-like Growth Factor-1 Receptor (IGF1R) Tyrosine Kinase as a Novel Cancer Therapy Approach. J. Med. Chem. 2009, 52, 4981-5004. [CrossRef]

114. Pillai, R.N.; Ramalingam, S.S. Inhibition of insulin-like growth factor receptor: End of a targeted therapy? Transl. Lung Cancer Res. 2013, 2, 14-22. [CrossRef]

115. Beckwith, H.; Yee, D. Minireview: Were the IGF Signaling Inhibitors All Bad? Mol. Endocrinol. 2015, 29, 1549-1557. [CrossRef]

116. Ekyalongo, R.C.; Yee, D. Revisiting the IGF-1R as a breast cancer target. NPG Precis. Oncol. 2017, 1, 59. [CrossRef]

117. Qu, X.; Wu, Z.; Dong, W.; Zhang, T.; Wang, L.; Pang, Z.; Ma, W.; Du, J. Update of IGF-1 receptor inhibitor (ganitumab, dalotuzumab, cixutumumab, teprotumumab and figitumumab) effects on cancer therapy. Oncotarget 2017, 8, 29501-29518. [CrossRef]

118. Trojan, J.; Johnson, T.; Rudin, S.; Tykocinski, M.; Ilan, J. Treatment and prevention of rat glioblastoma by immunogenic C6 cells expressing antisense insulin-like growth factor I RNA. Science 1993, 259, 94-97. [CrossRef]

119. Resnicoff, M.; Sell, C.; Rubini, M.; Coppola, D.; Ambrose, D.; Baserga, R.; Rubin, R. Rat glioblastoma cells expressing an antisense RNA to the insulin-like growth factor-1 (IGF-1) receptor are nontumorigenic and induce regression of wild-type tumors. Cancer Res. 1994, 54, 2218-2222.

120. Andrews, D.W.; Resnicoff, M.; Flanders, A.E.; Kenyon, L.; Curtis, M.; Merli, G.; Baserga, R.; Iliakis, G.; Aiken, R.D. Results of a Pilot Study Involving the Use of an Antisense Oligodeoxynucleotide Directed Against the Insulin-Like Growth Factor Type I Receptor in Malignant Astrocytomas. J. Clin. Oncol. 2001, 19, 2189-2200. [CrossRef]

121. Wraight, C.J.; White, P.J.; Mckean, S.C.; Fogarty, R.D.; Venables, D.J.; Liepe, I.J.; Edmondson, S.R.; Werther, G.A. Reversal of epidermal hyperproliferation in psoriasis by insulin-like growth factor I receptor antisense oligonucleotides. Nat. Biotechnol. 2000, 18, 521-526. [CrossRef]

122. Furukawa, J.; Wraight, C.J.; Freier, S.M.; Peralta, E.; Atley, L.M.; Monia, B.P.; Gleave, M.E.; Cox, M.E. Antisense oligonucleotide targeting of insulin-like growth factor-1 receptor (IGF-1R) in prostate cancer. Prostate 2010, 70, 206-218. [CrossRef] 
123. Fire, A.; Xu, S.; Montgomery, M.K.; Kostas, S.A.; Driver, S.E.; Mello, C.C. Potent and specific genetic interference by double-stranded RNA in Caenorhabditis elegans. Nature 1998, 391, 806-811. [CrossRef]

124. Elbashir, S.M.; Harborth, J.; Lendeckel, W.; Yalcin, A.; Weber, K.; Tuschl, T. Duplexes of 21-nucleotide RNAs mediate RNA interference in cultured mammalian cells. Nature 2001, 411, 494-498. [CrossRef]

125. Castel, S.E.; Martienssen, R.A. RNA interference (RNAi) in the Nucleus: Roles for small RNA in transcription, epigenetics and beyond. Nat. Rev. Genet. 2013, 14, 100-112. [CrossRef]

126. Bohula, E.A.; Salisbury, A.J.; Sohail, M.; Playford, M.P.; Riedemann, J.; Southern, E.M.; Macaulay, V.M. The Efficacy of Small Interfering RNAs Targeted to the Type 1 Insulin-like Growth Factor Receptor (IGF1R) Is Influenced by Secondary Structure in the IGF1R Transcript. J. Boil. Chem. 2003, 278, 15991-15997. [CrossRef]

127. Niu, J.; Xu, Z.; Li, X.; Han, Z. siRNA-mediated type 1 insulin-like growth factor receptor silencing induces chemosensitization of a human liver cancer cell line with mutant P53. Cell Boil. Int. 2007, 31, 156-164. [CrossRef]

128. Yuen, J.S.; Akkaya, E.; Wang, Y.; Takiguchi, M.; Peak, S.; Sullivan, M.; Protheroe, A.S.; Macaulay, V.M. Validation of the type 1 insulin-like growth factor receptor as a therapeutic target in renal cancer. Mol. Cancer. Ther. 2009, 8, 1448-1459. [CrossRef]

129. Turney, B.W.; Kerr, M.; Chitnis, M.M.; Lodhia, K.; Wang, Y.; Riedemann, J.; Rochester, M.; Protheroe, A.S.; Brewster, S.F.; Macaulay, V.M. Depletion of the type 1 IGF receptor delays repair of radiation-induced DNA double strand breaks. Radiother. Oncol. 2012, 103, 402-409. [CrossRef]

130. Zhao, H.; Gu, X. Silencing of insulin-like growth factor-1 receptor enhances the radiation sensitivity of human esophageal squamous cell carcinoma in vitro and in vivo. World J. Surg. Oncol. 2014, 12, 325. [CrossRef]

131. Soutschek, J.; Akinc, A.; Bramlage, B.; Charisse, K.; Constien, R.; Donoghue, M.; Elbashir, S.; Geick, A.; Hadwiger, P.; Harborth, J.; et al. Therapeutic silencing of an endogenous gene by systemic administration of modified siRNAs. Nature 2004, 432, 173-178. [CrossRef]

132. D'Ambrosio, C.; Ferber, A.; Resnicoff, M.; Baserga, R. A soluble insulin-like growth factor I receptor that induces apoptosis of tumor cells in vivo and inhibits tumorigenesis. Cancer Res. 1996, 56.

133. Dunn, S.; Ehrlich, M.; Sharp, N.J.; Reiss, K.; Solomon, G.; Hawkins, R.; Baserga, R.; Barrett, J.C. A dominant negative mutant of the insulin-like growth factor-I receptor inhibits the adhesion, invasion, and metastasis of breast cancer. Cancer Res. 1998, 58, 3353-3361.

134. Samani, A.A.; Chevet, E.; Fallavollita, L.; Galipeau, J.; Brodt, P. Loss of tumorigenicity and metastatic potential in carcinoma cells expressing the extracellular domain of the type 1 insulin-like growth factor receptor. Cancer Res. 2004, 64, 3380-3385. [CrossRef]

135. Gan, Y.; Buckels, A.; Liu, Y.; Zhang, Y.; Paterson, A.J.; Jiang, J.; Zinn, K.R.; Frank, S.J. Human GH Receptor-IGF-1 Receptor Interaction: Implications for GH Signaling. Mol. Endocrinol. 2014, 28, 1841-1854. [CrossRef]

136. Sachdev, D.; Hartell, J.S.; Lee, A.V.; Zhang, X.; Yee, D. A dominant negative type I insulin-like growth factor receptor inhibits metastasis of human cancer cells. J. Biol. Chem. 2004, 279, 5017-5024. [CrossRef]

137. Min, Y.; Adachi, Y.; Yamamoto, H.; Imsumran, A.; Arimura, Y.; Endo, T.; Hinoda, Y.; Lee, C.-T.; Nadaf, S.; Carbone, D.P.; et al. Insulin-like growth factor I receptor blockade enhances chemotherapy and radiation responses and inhibits tumour growth in human gastric cancer xenografts. Gut 2005, 54, 591-600. [CrossRef]

138. Fujita, M.; Ieguchi, K.; Cedano-Prieto, D.M.; Fong, A.; Wilkerson, C.; Chen, J.Q.; Wu, M.; Lo, S.-H.; Cheung, A.T.W.; Wilson, M.D.; et al. An Integrin Binding-defective Mutant of Insulin-like Growth Factor-1 (R36E/R37E IGF1) Acts as a Dominant-negative Antagonist of the IGF1 Receptor (IGF1R) and Suppresses Tumorigenesis but Still Binds to IGF1R. J. Boil. Chem. 2013, 288, 19593-19603. [CrossRef]

139. Husain, S.R.; Han, J.; Au, P.; Shannon, K.; Puri, R.K. Gene therapy for cancer: Regulatory considerations for approval. Cancer Gene Ther. 2015, 22, 554-563. [CrossRef]

140. Sachdev, D.; Li, S.-L.; Hartell, J.S.; Fujita-Yamaguchi, Y.; Miller, J.S.; Yee, D. A chimeric humanized single-chain antibody against the type I insulin-like growth factor (IGF) receptor renders breast cancer cells refractory to the mitogenic effects of IGF-I. Cancer Res. 2003, 63, 627-635.

141. Sachdev, D.; Singh, R.; Fujita-Yamaguchi, Y.; Yee, D. Down-regulation of Insulin Receptor by Antibodies against the Type I Insulin-Like Growth Factor Receptor: Implications for Anti-Insulin-Like Growth Factor Therapy in Breast Cancer. Cancer Res. 2006, 66, 2391-2402. [CrossRef]

142. Pandini, G.; Wurch, T.; Akla, B.; Corvaia, N.; Belfiore, A.; Goetsch, L. Functional responses and in vivo anti-tumour activity of h7C10: A humanised monoclonal antibody with neutralising activity against the 
insulin-like growth factor-1 (IGF-1) receptor and insulin/IGF-1 hybrid receptors. Eur. J. Cancer 2007, 43, 1318-1327. [CrossRef]

143. Pollak, M.N.; Schernhammer, E.S.; Hankinson, S.E. Insulin-like growth factors and neoplasia. Nat. Rev. Cancer 2004, 4, 505-518. [CrossRef]

144. Ulanet, D.B.; Ludwig, D.L.; Kahn, C.R.; Hanahan, D. Insulin receptor functionally enhances multistage tumor progression and conveys intrinsic resistance to IGF-1R targeted therapy. Proc. Natl. Acad. Sci. 2010, 107, 10791-10798. [CrossRef]

145. Buck, E.; Gokhale, P.C.; Koujak, S.; Brown, E.; Eyzaguirre, A.; Tao, N.; Rosenfeld-Franklin, M.; Lerner, L.; Chiu, M.I.; Wild, R.; et al. Compensatory Insulin Receptor (IR) Activation on Inhibition of Insulin-Like Growth Factor-1 Receptor (IGF-1R): Rationale for Cotargeting IGF-1R and IR in Cancer. Mol. Cancer Ther. 2010, 9, 2652-2664. [CrossRef]

146. Weinstein, D.; Sarfstein, R.; Laron, Z.; Werner, H. Insulin receptor compensates for IGF1R inhibition and directly induces mitogenic activity in prostate cancer cells. Endocr. Connect. 2014, 3, 24-35. [CrossRef]

147. Forest, A.; Amatulli, M.; Ludwig, D.L.; Damoci, C.B.; Wang, Y.; Burns, C.A.; Donoho, G.P.; Zanella, N.; Fiebig, H.H.; Prewett, M.C.; et al. Intrinsic Resistance to Cixutumumab is Conferred by Distinct Isoforms of the Insulin Receptor. Mol. Cancer Res. 2015, 13, 1615-1626. [CrossRef]

148. Bid, H.K.; Zhan, J.; Phelps, D.A.; Kurmasheva, R.T.; Houghton, P.J. Potent inhibition of angiogenesis by the IGF-1 receptor-targeting antibody SCH717454 is reversed by IGF-2. Mol. Cancer Ther. 2012, 11, 649-659. [CrossRef]

149. Feng, Y.; Dimitrov, D.S. Antibody-based therapeutics against components of the IGF system. OncoImmunology 2012, 1, 1390-1391. [CrossRef]

150. Veeken, J.; Oliveira, S.; Schiffelers, R.; Storm, G.; Henegouwen, P.; Roovers, R. Crosstalk Between Epidermal Growth Factor Receptor- and Insulin-Like Growth Factor-1 Receptor Signaling: Implications for Cancer Therapy. Curr. Cancer Drug Targets 2009, 9, 748-760. [CrossRef]

151. Liu, R.; Tang, W.; Han, X.; Geng, R.; Wang, C.; Zhang, Z. Hepatocyte growth factor-induced mesenchymal-epithelial transition factor activation leads to insulin-like growth factor 1 receptor inhibitor unresponsiveness in gastric cancer cells. Oncol. Lett. 2018, 16, 5983-5991. [CrossRef]

152. Cohen, B.D.; Baker, D.A.; Soderstrom, C.; Tkalcevic, G.; Rossi, A.M.; Miller, P.E.; Tengowski, M.W.; Wang, F.; Gualberto, A.; Beebe, J.S.; et al. Combination Therapy Enhances the Inhibition of Tumor Growth with the Fully Human Anti-Type 1 Insulin-Like Growth Factor Receptor Monoclonal Antibody CP-751,871. Clin. Cancer Res. 2005, 11, 2063-2073. [CrossRef]

153. Lacy, M.Q.; Alsina, M.; Fonseca, R.; Paccagnella, M.L.; Melvin, C.L.; Yin, D.; Sharma, A.; Sarano, M.E.; Pollak, M.; Jagannath, S.; et al. Phase I, Pharmacokinetic and Pharmacodynamic Study of the Anti-Insulinlike Growth Factor Type 1 Receptor Monoclonal Antibody CP-751,871 in Patients with Multiple Myeloma. J. Clin. Oncol. 2008, 26, 3196-3203. [CrossRef]

154. Pavlicek, A.; Lira, M.E.; Lee, N.V.; Ching, K.A.; Ye, J.; Cao, J.; Garza, S.J.; Hook, K.E.; Ozeck, M.; Shi, S.T.; et al. Molecular Predictors of Sensitivity to the Insulin-like Growth Factor 1 Receptor Inhibitor Figitumumab (CP-751,871). Mol. Cancer Ther. 2013, 12, 2929-2939. [CrossRef]

155. De Bono, J.S.; Piulats, J.M.; Pandha, H.S.; Petrylak, D.P.; Saad, F.; Aparicio, L.M.A.; Sandhu, S.K.; Fong, P.; Gillessen, S.; Hudes, G.R.; et al. Phase II Randomized Study of Figitumumab plus Docetaxel and Docetaxel Alone with Crossover for Metastatic Castration-Resistant Prostate Cancer. Clin. Cancer Res. 2014, 20, 1925-1934. [CrossRef]

156. Calvo, E.; Soria, J.C.; Ma, W.W.; Wang, T.; Bahleda, R.; Tolcher, A.W.; Gernhardt, D.; O'Connell, J.; Millham, R.; Giri, N.; et al. A Phase I Clinical Trial and Independent Patient-Derived Xenograft Study of Combined Targeted Treatment with Dacomitinib and Figitumumab in Advanced Solid Tumors. Clin. Cancer Res. 2017, 23, 1177-1185. [CrossRef]

157. Tolcher, A.W.; Sarantopoulos, J.; Patnaik, A.; Papadopoulos, K.; Rodon, J.; Murphy, B.; Roth, B.; McCaffery, I.; Gorski, K.S.; Kaiser, B.; et al. Phase I, Pharmacokinetic, and Pharmacodynamic Study of AMG 479, a Fully Human Monoclonal Antibody to Insulin-Like Growth Factor Receptor 1. J. Clin. Oncol. 2009, 27, 5800-5807. [CrossRef]

158. Beltran, P.J.; Chung, Y.-A.; Moody, G.; Mitchell, P.; Cajulis, E.; Vonderfecht, S.; Kendall, R.; Radinsky, R.; Calzone, F.J. Efficacy of Ganitumab (AMG 479), Alone and in Combination with Rapamycin, in Ewing's and Osteogenic Sarcoma Models. J. Pharmacol. Exp. Ther. 2011, 337, 644-654. [CrossRef] 
159. Glisson, B.; Besse, B.; Dols, M.C.; Dubey, S.; Schupp, M.; Jain, R.; Jiang, Y.; Menon, H.; Nackaerts, K.; Orlov, S.; et al. A Randomized, Placebo-Controlled, Phase 1b/2 Study of Rilotumumab or Ganitumab in Combination with Platinum-Based Chemotherapy as First-Line Treatment for Extensive-Stage Small-Cell Lung Cancer. Clin. Lung Cancer 2017, 18, 615-625. [CrossRef]

160. Kurzrock, R.; Patnaik, A.; Aisner, J.; Warren, T.; Leong, S.; Benjamin, R.; Eid, J.E.; Habben, K.; McCarthy, C.D.; Gore, L.; et al. A Phase I Study of Weekly R1507, A Human Monoclonal Antibody Insulin-like Growth Factor-I Receptor Antagonist, in Patients with Advanced Solid Tumors. Clin. Cancer Res. 2010, 16, 2458-2465. [CrossRef]

161. Ramalingam, S.S.; Spigel, D.R.; Chen, D.; Steins, M.B.; Engelman, J.A.; Schneider, C.-P.; Novello, S.; Eberhardt, W.E.; Crino, L.; Habben, K.; et al. Randomized Phase II Study of Erlotinib in Combination With Placebo or R1507, a Monoclonal Antibody to Insulin-Like Growth Factor-1 Receptor, for Advanced-Stage Non-Small-Cell Lung Cancer. J. Clin. Oncol. 2011, 29, 4574-4580. [CrossRef]

162. Pappo, A.S.; Patel, S.R.; Crowley, J.; Reinke, D.K.; Kuenkele, K.-P.; Chawla, S.P.; Toner, G.C.; Maki, R.G.; Meyers, P.A.; Chugh, R.; et al. R1507, a Monoclonal Antibody to the Insulin-Like Growth Factor 1 Receptor, in Patients With Recurrent or Refractory Ewing Sarcoma Family of Tumors: Results of a Phase II Sarcoma Alliance for Research Through Collaboration Study. J. Clin. Oncol. 2011, 29, 4541-4547. [CrossRef]

163. Pappo, A.S.; Vassal, G.; Crowley, J.J.; Bolejack, V.; Hogendoorn, P.C.W.; Chugh, R.; Ladanyi, M.; Grippo, J.F.; Dall, G.; Staddon, A.P.; et al. A phase 2 trial of R1507, a monoclonal antibody to the insulin-like growth factor-1 receptor (IGF-1R), in patients with recurrent or refractory rhabdomyosarcoma, osteosarcoma, synovial sarcoma, and other soft tissue sarcomas: Results of a Sarcoma Alliance. Cancer 2014, 120, 2448-2456. [CrossRef]

164. Atzori, F.; Tabernero, J.; Cervantes, A.; Prudkin, L.; Andreu, J.; Rodríguez-Braun, E.; Domingo, A.; Guijarro, J.; Gamez, C.; Rodon, J.; et al. A Phase I Pharmacokinetic and Pharmacodynamic Study of Dalotuzumab (MK-0646), an Anti-Insulin-like Growth Factor-1 Receptor Monoclonal Antibody, in Patients with Advanced Solid Tumors. Clin. Cancer Res. 2011, 17, 6304-6312. [CrossRef]

165. Brana, I.; Berger, R.; Golan, T.; Haluska, P.; Edenfield, J.; Fiorica, J.; Stephenson, J.; Martin, L.P.; Westin, S.; Hanjani, P.; et al. A parallel-arm phase I trial of the humanised anti-IGF-1R antibody dalotuzumab in combination with the AKT inhibitor MK-2206, the mTOR inhibitor ridaforolimus, or the NOTCH inhibitor MK-0752, in patients with advanced solid tumours. Br. J. Cancer 2014, 111, 1932-1944. [CrossRef]

166. Huang, C.H.; Williamson, S.K.; Neupane, P.; Taylor, S.A.; Allen, A.; Smart, N.J.; Uypeckcuat, A.M.; Spencer, S.; Wick, J.; Smith, H.; et al. Impact Study: MK-0646 (Dalotuzumab), Insulin Growth Factor 1 Receptor Antibody Combined with Pemetrexed and Cisplatin in Stage IV Metastatic Non-squamous Lung Cancer. Front Oncol. 2016, 5, 301. [CrossRef]

167. Sclafani, F.; Kim, T.Y.; Cunningham, D.; Kim, T.W.; Tabernero, J.; Schmoll, H.J.; Roh, J.K.; Kim, S.Y.; Park, Y.S.; Guren, T.K.; et al. A Randomized Phase II/III Study of Dalotuzumab in Combination With Cetuximab and Irinotecan in Chemorefractory, KRASWild-Type, Metastatic Colorectal Cancer. J. Natl. Cancer Inst. 2015, 107. [CrossRef]

168. Rowinsky, E.K.; Youssoufian, H.; Tonra, J.R.; Solomon, P.; Burtrum, D.; Ludwig, D.L. IMC-A12, a Human IgG1 Monoclonal Antibody to the Insulin-Like Growth Factor I Receptor. Clin. Cancer Res. 2007, 13, 5549-5555. [CrossRef]

169. Attias-Geva, Z.; Bentov, I.; Ludwig, D.L.; Fishman, A.; Bruchim, I.; Werner, H. Insulin-like growth factor-I receptor (IGF-IR) targeting with monoclonal antibody cixutumumab (IMC-A12) inhibits IGF-I action in endometrial cancer cells. Eur. J. Cancer 2011, 47, 1717-1726. [CrossRef]

170. Malempati, S.; Weigel, B.; Ingle, A.M.; Ahern, C.H.; Carroll, J.M.; Roberts, C.T.; Reid, J.M.; Schmechel, S.; Voss, S.D.; Cho, S.Y.; et al. Phase I/II trial and pharmacokinetic study of cixutumumab in pediatric patients with refractory solid tumors and Ewing sarcoma: A report from the Children's Oncology Group. J. Clin. Oncol. 2012, 30, 256-262. [CrossRef]

171. Yu, E.Y.; Li, H.; Higano, C.S.; Agarwal, N.; Pal, S.K.; Alva, A.; Heath, E.I.; Lam, E.T.; Gupta, S.; Lilly, M.B.; et al. SWOG S0925: A Randomized Phase II Study of Androgen Deprivation Combined With Cixutumumab Versus Androgen Deprivation Alone in Patients With New Metastatic Hormone-Sensitive Prostate Cancer. Cli. Oncol. 2015, 33, 1601-1608. [CrossRef] 
172. Wang, Y.; Hailey, J.; Williams, D.; Lipari, P.; Malkowski, M.; Xie, L.; Li, G.; Saha, D.; Ling, W.L.W.; Cannon-Carlson, S.; et al. Inhibition of insulin-like growth factor-I receptor (IGF-IR) signaling and tumor cell growth by a fully human neutralizing anti-IGF-IR antibody. Mol. Cancer Ther. 2005, 4, 1214-1221. [CrossRef]

173. Anderson, P.M.; Bielack, S.S.; Gorlick, R.G.; Skubitz, K.; Daw, N.C.; Herzog, C.E.; Monge, O.R.; Lassaletta, A.; Boldrini, E.; Pápai, Z.; et al. A phase II study of clinical activity of SCH 717454 (robatumumab) in patients with relapsed osteosarcoma and Ewing sarcoma. Pediatr. Blood Cancer 2016, 63, 1761-1770. [CrossRef]

174. Fitzgerald, J.B.; Johnson, B.W.; Baum, J.; Adams, S.; Iadevaia, S.; Tang, J.; Rimkunas, V.; Xu, L.; Kohli, N.; Rennard, R.; et al. MM-141, an IGF-IR-and ErbB3-directed bispecific antibody, overcomes network adaptations that limit activity of IGF-IR inhibitors. Mol. Cancer Ther. 2014, 13, 410-425. [CrossRef]

175. Kandasamy Hariharan, J.D.; Demarest, S.; Joseph, I.; Chu, P.; Graff, C.; Glaser, S.; Kramer-Stickland, K.; Peach, R.; Reff, M. BIIB022, a fully human nonglycosylated $\gamma 4 \mathrm{P}$ antibody targeting IGF-1R for cancer therapy. Mol Cancer Ther 2007, 6.

176. Von Mehren, M.; Britten, C.D.; Pieslor, P.; Saville, W.; Vassos, A.; Harris, S.; Galluppi, G.R.; Darif, M.; Wainberg, Z.A.; Cohen, R.B.; et al. A phase 1, open-label, dose-escalation study of BIIB022 (anti-IGF-1R monoclonal antibody) in subjects with relapsed or refractory solid tumors. Investig. New Drugs 2014, 32, 518-525. [CrossRef]

177. Gualberto, A.; Hixon, M.L.; Pollak, M. Reply: ‘Pre-treatment levels of circulating free IGF-1 identify NSCLC patients who derive clinical benefit from figitumumab'. Br. J. Cancer 2011, 105, 1467. [CrossRef]

178. Van Maldegem, A.M.; Bovee, J.V.; Peterse, E.F.; Hogendoorn, P.C.; Gelderblom, H. Ewing sarcoma: The clinical relevance of the insulin-like growth factor 1 and the poly-ADP-ribose-polymerase pathway. Eur. J. Cancer 2016, 53, 171-180. [CrossRef]

179. García-Echeverría, C.; A. Pearson, M.; Marti, A.; Meyer, T.; Mestan, J.; Zimmermann, J.; Gao, J.; Brueggen, J.; Capraro, H.-G.; Cozens, R.; et al. In vivo antitumor activity of NVP-AEW541-A novel, potent, and selective inhibitor of the IGF-IR kinase. Cancer Cell 2004, 5, 231-239.

180. Favelyukis, S.; Till, J.H.; Hubbard, S.; Miller, W.T. Structure and autoregulation of the insulin-like growth factor 1 receptor kinase. Nat. Genet. 2001, 8, 1058-1063.

181. Mulvihill, M.J.; Cooke, A.; Rosenfeld-Franklin, M.; Buck, E.; Foreman, K.; Landfair, D.; O’Connor, M.; Pirritt, C.; Sun, Y.; Yao, Y.; et al. Discovery of OSI-906: A selective and orally efficacious dual inhibitor of the IGF-1 receptor and insulin receptor. Futur. Med. Chem. 2009, 1, 1153-1171. [CrossRef]

182. Carboni, J.M.; Wittman, M.; Yang, Z.; Lee, F.; Greer, A.; Hurlburt, W.; Hillerman, S.; Cao, C.; Cantor, G.H.; Dell-John, J.; et al. BMS-754807, a small molecule inhibitor of insulin-like growth factor-1R/IR. Mol. Cancer Ther. 2009, 8, 3341-3349. [CrossRef]

183. Weroha, S.J.; Haluska, P. IGF-1 Receptor Inhibitors in Clinical Trials-Early Lessons. J. Mammary Gland. Boil. Neoplasia 2008, 13, 471-483. [CrossRef]

184. Leighl, N.B.; de Rizvi, N.A.; Lima, L.G., Jr.; Arpornwirat, W.; Rudin, C.M.; Chiappori, A.A.; Ahn, M.J.; Chow, L.Q.; Bazhenova, L.; Dechaphunkul, A. Phase 2 Study of Erlotinib in Combination With Linsitinib (OSI-906) or Placebo in Chemotherapy-Naive Patients With Non-Small-Cell Lung Cancer and Activating Epidermal Growth Factor Receptor Mutations. Clin. Lung Cancer 2017, 18, 34-42 e2. [CrossRef]

185. Jones, R.L.; Kim, E.S.; Nava-Parada, P.; Alam, S.; Johnson, F.M.; Stephens, A.W.; Simantov, R.; Poondru, S.; Gedrich, R.; Lippman, S.M.; et al. Phase I study of intermittent oral dosing of the insulin-like growth factor-1 and insulin receptors inhibitor OSI-906 in patients with advanced solid tumors. Clin. Cancer Res. 2015, 21, 693-700. [CrossRef]

186. Macaulay, V.M.; Middleton, M.R.; Eckhardt, S.G.; Rudin, C.M.; Juergens, R.A.; Gedrich, R.; Gogov, S.; McCarthy, S.; Poondru, S.; Stephens, A.W.; et al. Phase I Dose-Escalation Study of Linsitinib (OSI-906) and Erlotinib in Patients with Advanced Solid Tumors. Clin. Cancer Res. 2016, 22, 2897-2907. [CrossRef]

187. Oza, A.; Kaye, S.; Van Tornout, J.; Sessa, C.; Gore, M.; Naumann, R.W.; Hirte, H.; Colombo, N.; Chen, J.; Gorla, S.; et al. Phase 2 study evaluating intermittent and continuous linsitinib and weekly paclitaxel in patients with recurrent platinum resistant ovarian epithelial cancer. Gynecol. Oncol. 2018, 149, 275-282. [CrossRef]

188. Youngren, J.F.; Gable, K.; Penaranda, C.; Maddux, B.A.; Zavodovskaya, M.; Lobo, M.; Campbell, M.; Kerner, J.; Goldfine, I.D. Nordihydroguaiaretic Acid (NDGA) Inhibits the IGF-1 and c-erbB2/HER2/neu Receptors and Suppresses Growth in Breast Cancer Cells. Breast Cancer Res. Treat. 2005, 94, 37-46. [CrossRef] 
189. Cortes, J.; Paquette, R.; Talpaz, M.; Pinilla, J.; Asatiani, E.; Wetzler, M.; Lipton, J.H.; Kasap, C.; Bui, L.A.; Clary, D.O.; et al. Preliminary Clinical Activity in a Phase I Trial of the BCR-ABL/IGF- 1R/Aurora Kinase Inhibitor XL228 in Patients with $\mathrm{Ph}^{+}+$Leukemias with Either Failure to Multiple TKI Therapies or with T315I Mutation. Blood 2008, 112, 3232.

190. Waraky, A.; Akopyan, K.; Parrow, V.; Strömberg, T.; Axelson, M.; Abrahmsén, L.; Lindqvist, A.; Larsson, O.; Aleem, E. Picropodophyllin causes mitotic arrest and catastrophe by depolymerizing microtubules via Insulin-like growth factor-1 receptor-independent mechanism. Oncotarget 2014, 5, 8379-8392. [CrossRef]

191. Aiken, R.; Axelson, M.; Harmenberg, J.; Klockare, M.; Larsson, O.; Wassberg, C. Phase I clinical trial of AXL1717 for treatment of relapsed malignant astrocytomas: Analysis of dose and response. Oncotarget 2017, 8, 81501-81510. [CrossRef]

192. Fassnacht, M.; Berruti, A.; Baudin, E.; Demeure, M.J.; Gilbert, J.; Haak, H.; Kroiss, M.I.; Quinn, D.; Hesseltine, E.; Ronchi, C.L.; et al. Linsitinib (OSI-906) versus placebo for patients with locally advanced or metastatic adrenocortical carcinoma: A double-blind, randomised, phase 3 study. Lancet Oncol. 2015, 16, 426-435. [CrossRef]

193. Barata, P.; Cooney, M.; Tyler, A.; Wright, J.; Dreicer, R.; Garcia, J.A. A phase 2 study of OSI-906 (linsitinib, an insulin-like growth factor receptor-1 inhibitor) in patients with asymptomatic or mildly symptomatic (non-opioid requiring) metastatic castrate resistant prostate cancer (CRPC). Investig. New Drugs 2018, 36, 451-457. [CrossRef]

194. Haluska, P.; Dhar, A.; Hou, X.; Huang, F.; Nuyten, D.S.A.; Park, J.; Brodie, A.H.; Ingle, J.N.; Carboni, J.M.; Gottardis, M.M.; et al. Phase II trial of the dual IGF-1R/IR inhibitor BMS-754807 with or without letrozole in aromatase inhibitor-resistant breast cancer. J. Clin. Oncol. 2011, 29, TPS111. [CrossRef]

195. Toretsky, J.A.; Steinberg, S.M.; Thakar, M.; Counts, D.; Pironis, B.; Parente, C.; Eskenazi, A.; Helman, L.; Wexler, L.H. Insulin-like growth factor type 1 (IGF-1) and IGF binding protein-3 in patients with Ewing sarcoma family of tumors. Cancer 2001, 92, 2941-2947. [CrossRef]

196. Girnita, L.; Del Prete, F.; Bartolazzi, A.; Larsson, O.; Axelson, M. Cyclolignans as Inhibitors of the Insulin-Like Growth Factor-1 Receptor and Malignant Cell Growth. Cancer Res. 2004, 64, 236-242. [CrossRef]

197. Bergqvist, M.; Holgersson, G.; Bondarenko, I.; Grechanaya, E.; Maximovich, A.; Andor, G.; Klockare, M.; Thureson, M.; Jerling, M.; Harmenberg, J. Phase II randomized study of the IGF-1R pathway modulator AXL1717 compared to docetaxel in patients with previously treated, locally advanced or metastatic non-small cell lung cancer. Acta. Oncol. 2017, 56, 441-447. [CrossRef]

198. Ryan, C.J.; Harzstark, A.H.; Rosenberg, J.; Lin, A.; Claros, C.; Goldfine, I.D.; Kerner, J.F.; Small, E.J. A pilot dose-escalation study of the effects of nordihydroguareacetic acid on hormone and prostate specific antigen levels in patients with relapsed prostate cancer. BJU Int. 2008, 101, 436-439. [CrossRef]

199. Friedlander, T.W.; Weinberg, V.K.; Huang, Y.; Mi, J.T.; Formaker, C.G.; Small, E.J.; Harzstark, A.L.; Lin, A.M.; Fong, L.; Ryan, C.J. A phase II study of insulin-like growth factor receptor inhibition with nordihydroguaiaretic acid in men with non-metastatic hormone-sensitive prostate cancer. Oncol. Rep. 2012, 27, 3-9. [CrossRef]

200. Gao, J.; Chesebrough, J.W.; Cartlidge, S.A.; Ricketts, S.-A.; Incognito, L.; Veldman-Jones, M.; Blakey, D.C.; Tabrizi, M.; Jallal, B.; Trail, P.A.; et al. Dual IGF-I/II-Neutralizing Antibody MEDI-573 Potently Inhibits IGF Signaling and Tumor Growth. Cancer Res. 2011, 71, 1029-1040. [CrossRef]

201. Haluska, P.; Menefee, M.; Plimack, E.R.; Rosenberg, J.; Northfelt, D.; Lavallee, T.; Shi, L.; Yu, X.-Q.; Burke, P.; Huang, J.; et al. Phase I Dose-Escalation Study of MEDI-573, a Bispecific, Antiligand Monoclonal Antibody against IGFI and IGFII, in Patients with Advanced Solid Tumors. Clin. Cancer Res. 2014, 20, 4747-4757. [CrossRef]

202. Friedbichler, K.; Hofmann, M.H.; Kroez, M.; Ostermann, E.; Lamche, H.R.; Koessl, C.; Borges, E.; Pollak, M.N.; Adolf, G.; Adam, P.J. Pharmacodynamic and antineoplastic activity of BI 836845, a fully human IGF ligand-neutralizing antibody, and mechanistic rationale for combination with rapamycin. Mol. Cancer Ther. 2014, 13, 399-409. [CrossRef]

203. Mireuta, M.; Birman, E.; Barmash, M.; Pollak, M. Quantification of Binding of IGF-1 to BI 836845, a Candidate Therapeutic Antibody Against IGF-1 and IGF-2, and Effects of This Antibody on IGF-1:IGFBP-3 Complexes In Vitro and in Male C57BL/6 Mice. Endocrinology 2014, 155, 703-715. [CrossRef]

204. Hussain, S.A.; Maroto, P.; Climent, M.Á.; Bianchini, D.; Jones, R.H.; Lin, C.C.; Wang, S.S.; Dean, E.; Crossley, K.; Schlieker, L.; et al. Targeting IGF-1/2 with xentuzumab (Xe) plus enzalutamide (En) in metastatic 
castration-resistant prostate cancer (mCRPC) after progression on docetaxel chemotherapy (DCt) and abiraterone (Abi): Randomized phase II trial results. J. Clin. Oncol. 2019, 37, abstr-5030. [CrossRef]

205. Crown, J.; Sablin, M.P.; Cortés, J.; Bergh, J.; Im, S.A.; Lu, Y.S.; Martínez, N.; Neven, P.; Lee, K.S.; Morales, S.; et al. Abstract P6-21-01: Xentuzumab (BI 836845), an insulin-like growth factor (IGF)-neutralizing antibody (Ab), combined with exemestane and everolimus in hormone receptor-positive $(\mathrm{HR}+)$ locally advanced/metastatic breast cancer (LA/mBC): Randomized phase 2 results. Cancer Res. 2019, 79, P6-21. [CrossRef]

206. Zhang, X.H.-F.; Jin, X.; Malladi, S.; Zou, Y.; Wen, Y.H.; Brogi, E.; Smid, M.; Foekens, J.A.; Massagué, J. Selection of Bone Metastasis Seeds by Mesenchymal Signals in the Primary Tumor Stroma. Cell 2013, 154, 1060-1073. [CrossRef]

207. Santarlasci, B.; Vaiani, M.; Messori, A. New Drugs for Rheumatoid Arthritis. New Engl. J. Med. 2004, 351, 937-938.

208. Zhao, S.; Mysler, E.; Moots, R.J. Etanercept for the treatment of rheumatoid arthritis. Immunother 2018, 10, 433-445. [CrossRef]

209. Holash, J.; Davis, S.; Papadopoulos, N.; Croll, S.D.; Ho, L.; Russell, M.; Boland, P.; Leidich, R.; Hylton, D.; Burova, E.; et al. VEGF-Trap: A VEGF blocker with potent antitumor effects. Proc. Natl. Acad. Sci. 2002, 99, 11393-11398. [CrossRef]

210. Apte, R.S.; Chen, D.S.; Ferrara, N. VEGF in Signaling and Disease: Beyond Discovery and Development. Cell 2019, 176, 1248-1264. [CrossRef]

211. Prince, S.N.; Foulstone, E.J.; Zaccheo, O.J.; Williams, C.; Hassan, A.B. Functional evaluation of novel soluble insulin-like growth factor (IGF)-II-specific ligand traps based on modified domain 11 of the human IGF2 receptor. Mol. Cancer Ther. 2007, 6, 607-617. [CrossRef]

212. Frago, S.; Nicholls, R.D.; Strickland, M.; Hughes, J.; Williams, C.; Garner, L.; Surakhy, M.; MacLean, R.; Rezgui, D.; Prince, S.N.; et al. Functional evolution of IGF2:IGF2R domain 11 binding generates novel structural interactions and a specific IGF2 antagonist. Proc. Natl. Acad. Sci. 2016, 113, E2766-E2775. [CrossRef]

213. Wang, N.; Rayes, R.F.; Elahi, S.M.; Lu, Y.; Hancock, M.A.; Massie, B.; Rowe, G.E.; Aomari, H.; Hossain, S.; Durocher, Y.; et al. The IGF-Trap: Novel Inhibitor of Carcinoma Growth and Metastasis. Mol. Cancer Ther. 2015, 14, 982-993. [CrossRef]

214. Vaniotis, G.; Moffett, S.; Sulea, T.; Wang, N.; Elahi, S.M.; Lessard, E.; Baardsnes, J.; Perrino, S.; Durocher, Y.; Frystyk, J.; et al. Enhanced anti-metastatic bioactivity of an IGF-TRAP re-engineered to improve physicochemical properties. Sci. Rep. 2018, 8, 17361. [CrossRef]

215. Lin, M.Z.; Marzec, K.A.; Martin, J.L.; Baxter, R.C. The role of insulin-like growth factor binding protein-3 in the breast cancer cell response to DNA-damaging agents. Oncogene 2014, 33, 85-96. [CrossRef]

216. de Martin, J.L.; Silva, H.C.; Lin, M.Z.; Scott, C.D.; Baxter, R.C. Inhibition of insulin-like growth factor-binding protein-3 signaling through sphingosine kinase-1 sensitizes triple-negative breast cancer cells to EGF receptor blockade. Mol. Cancer Ther. 2014, 13, 316-328. [CrossRef]

217. Jerome, L.; Alami, N.; Belanger, S.; Page, V.; Yu, Q.; Paterson, J.; Shiry, L.; Pegram, M.; Leyland-Jones, B. Recombinant Human Insulin-like Growth Factor Binding Protein 3 Inhibits Growth of Human Epidermal Growth Factor Receptor-2-Overexpressing Breast Tumors and Potentiates Herceptin Activity In vivo. Cancer Res. 2006, 66, 7245-7252. [CrossRef]

218. Conover, C.A. Key Questions and Answers about Pregnancy-Associated Plasma Protein-A. Trends Endocrinol. Metab. 2012, 23, 242-249. [CrossRef]

219. Becker, M.A.; Haluska, P.; Bale, L.K.; Oxvig, C.; Conover, C.A. A Novel Neutralizing Antibody Targeting Pregnancy-Associated Plasma Protein-A Inhibits Ovarian Cancer Growth and Ascites Accumulation in Patient Mouse Tumorgrafts. Mol. Cancer Ther. 2015, 14, 973-981. [CrossRef]

220. Conover, C.A.; Bale, L.K.; Mader, J.R.; Mason, M.A.; Keenan, K.P.; Marler, R.J. Longevity and Age-Related Pathology of Mice Deficient in Pregnancy-Associated Plasma Protein-A. J Gerontol. Ser. A. 2010, 65, 590-599. [CrossRef]

221. Conover, C.A. PAPP-A: A New Anti-Aging Target? Aging Cell 2010, 9, 942-946. [CrossRef]

222. Mondal, S.; Bandyopadhyay, S.; Ghosh, M.K.; Mukhopadhyay, S.; Roy, S.; Mandal, C. Natural products: Promising resources for cancer drug discovery. Anti-Cancer Agents Med. Chem. 2012, 12, 49-75. [CrossRef]

223. Sultana, N. Clinically useful anticancer, antitumor, and antiwrinkle agent, ursolic acid and related derivatives as medicinally important natural product. J. Enzym. Inhib. Med. Chem. 2011, 26, 616-642. [CrossRef] 
224. Amin, A.R.; Karpowicz, P.A.; Carey, T.E.; Arbiser, J.; Nahta, R.; Chen, Z.G.; Dong, J.T.; Kucuk, O.; Khan, G.N.; Huang, G.S.; et al. Evasion of anti-growth signaling: A key step in tumorigenesis and potential target for treatment and prophylaxis by natural compounds. Semin. Cancer Biol. 2015. [CrossRef]

225. Li, Y.; Zhang, T. Targeting cancer stem cells by curcumin and clinical applications. Cancer Lett. 2014, 346, 197-205. [CrossRef]

226. Babcook, M.A.; Gupta, S. Apigenin Modulates Insulin-like Growth Factor Axis: Implications for Prevention and Therapy of Prostate Cancer. Curr. Drug Targets 2012.

227. Jung, M.; Bu, S.Y.; Tak, K.-H.; Park, J.-E.; Kim, E. Anticarcinogenic effect of quercetin by inhibition of insulin-like growth factor (IGF)-1 signaling in mouse skin cancer. Nutr. Res. Pract. 2013, 7, 439-445. [CrossRef]

228. Kim, H.; Park, J.; Tak, K.H.; Bu, S.Y.; Kim, E. Chemopreventive effects of curcumin on chemically induced mouse skin carcinogenesis in BK5.insulin-like growth factor-1 transgenic mice. In Vitro Cell Dev. Biol. Anim. 2014, 50, 883-892. [CrossRef]

229. Hosseini, S.A.; Zand, H.; Cheraghpour, M. The Influence of Curcumin on the Downregulation of MYC, Insulin and IGF-1 Receptors: A Possible Mechanism Underlying the Anti-Growth and Anti-Migration in Chemoresistant Colorectal Cancer Cells. Medicine 2019, 55, 90. [CrossRef]

230. DeMichele, A.; Yee, D.; Berry, D.A.; Albain, K.S.; Benz, C.C.; Boughey, J.; Buxton, M.; Chia, S.K.; Chien, A.J.; Chui, S.Y.; et al. The Neoadjuvant Model Is Still the Future for Drug Development in Breast Cancer. Clin. Cancer Res. 2015, 21, 2911-2915. [CrossRef]

231. Lopez, J.S.; Banerji, U. Combine and conquer: Challenges for targeted therapy combinations in early phase trials. Nat. Rev. Clin. Oncol. 2017, 14, 57-66. [CrossRef]

232. Zeng, X.; Sachdev, D.; Zhang, H.; Gaillard-Kelly, M.; Yee, D. Sequencing of type I insulin-like growth factor receptor inhibition affects chemotherapy response in vitro and in vivo. Clin. Cancer Res. 2009, 15, 2840-2849. [CrossRef]

233. Ramcharan, R.; Aleksic, T.; Kamdoum, W.P.; Gao, S.; Pfister, S.X.; Tanner, J.; Bridges, E.; Asher, R.; Watson, A.J.; Margison, G.P.; et al. IGF-1R inhibition induces schedule-dependent sensitization of human melanoma to temozolomide. Oncotarget 2015, 6, 39877-39890. [CrossRef]

234. Baserga, R. The decline and fall of the IGF-I receptor. J Cell Physiol 2013, 228, 675-679. [CrossRef]

235. Olmos, D.; Postel-Vinay, S.; Molife, L.R.; Okuno, S.H.; Schuetze, S.M.; Paccagnella, M.L.; Batzel, G.N.; Yin, D.; Pritchard-Jones, K.; Judson, I.; et al. Safety, pharmacokinetics, and preliminary activity of the anti-IGF-1R antibody figitumumab (CP-751,871) in patients with sarcoma and Ewing's sarcoma: A phase 1 expansion cohort study. Lancet Oncol. 2010, 11, 11-129. [CrossRef]

236. Aleksic, T.; Browning, L.; Woodward, M.; Phillips, R.; Page, S.; Henderson, S.; Athanasou, N.; Ansorge, O.; Whitwell, D.; Pratap, S.; et al. Durable Response of Spinal Chordoma to Combined Inhibition of IGF-1R and EGFR. Front. Oncol. 2016, 6, 49. [CrossRef]

237. Sanderson, M.P.; Hofmann, M.H.; Garin-Chesa, P.; Schweifer, N.; Wernitznig, A.; Fischer, S.; Jeschko, A.; Meyer, R.; Moll, J.; Pecina, T.; et al. The IGF1R/INSR Inhibitor BI 885578 Selectively Inhibits Growth of IGF2-Overexpressing Colorectal Cancer Tumors and Potentiates the Efficacy of Anti-VEGF Therapy. Mol. Cancer Ther. 2017, 16, 2223-2233. [CrossRef]

238. Lee, H.; Kim, N.; Yoo, Y.J.; Kim, H.; Jeong, E.; Choi, S.; Moon, S.U.; Oh, S.H.; Mills, G.B.; Yoon, S.; et al. $\beta$-catenin/TCF activity regulates IGF-1R tyrosine kinase inhibitor sensitivity in colon cancer. Oncogene 2018, 37, 5466-5475. [CrossRef]

239. Wu, J.; Chen, K.; Zhang, F.; Jin, J.; Zhang, N.; Li, D.; Ying, L.; Chen, W.; Yu, H.; Mao, W.; et al. Overcoming Linsitinib intrinsic resistance through inhibition of nuclear factor- $\mathrm{\kappa} B$ signaling in esophageal squamous cell carcinoma. Cancer Med. 2017, 6, 1353-1361. [CrossRef]

240. Chen, H.; Mester, T.; Raychaudhuri, N.; Kauh, C.Y.; Gupta, S.; Smith, T.J.; Douglas, R.S. Teprotumumab, an IGF-1R Blocking Monoclonal Antibody Inhibits TSH and IGF-1 Action in Fibrocytes. J. Clin. Endocrinol. Metab. 2014, 99, E1635-E1640. [CrossRef]

241. Smith, T.J.; Kahaly, G.J.; Ezra, D.G.; Fleming, J.C.; Dailey, R.A.; Tang, R.A.; Harris, G.J.; Antonelli, A.; Salvi, M.; Goldberg, R.A.; et al. Teprotumumab for Thyroid-Associated Ophthalmopathy. New Engl. J. Med. 2017, 376, 1748-1761. [CrossRef] 
242. Smith, T.J.; Hegedus, L.; Douglas, R.S. Role of insulin-like growth factor-1 (IGF-1) pathway in the pathogenesis of Graves' orbitopathy. Best Pract. Res. Clin. Endocrinol. Metab. 2012, 26, 291-302. [CrossRef]

243. Longo, V.D.; Antebi, A.; Bartke, A.; Barzilai, N.; Brown-Borg, H.M.; Caruso, C.; Curiel, T.J.; De Cabo, R.; Franceschi, C.; Gems, D.; et al. Interventions to Slow Aging in Humans: Are We Ready? Aging Cell 2015, 14, 497-510. [CrossRef]

244. Mao, K.; Quipildor, G.F.; Tabrizian, T.; Novaj, A.; Guan, F.; Walters, R.O.; Delahaye, F.; Hubbard, G.B.; Ikeno, Y.; Ejima, K.; et al. Late-life targeting of the IGF-1 receptor improves healthspan and lifespan in female mice. Nat. Commun. 2018, 9, 2394. [CrossRef]

(C) 2019 by the authors. Licensee MDPI, Basel, Switzerland. This article is an open access article distributed under the terms and conditions of the Creative Commons Attribution (CC BY) license (http://creativecommons.org/licenses/by/4.0/). 